\title{
話 講
}

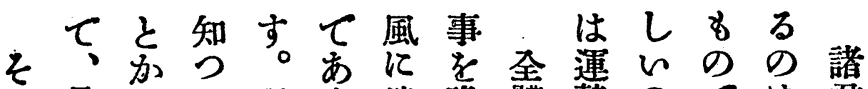
れ骨、七現ら遣豫體勢のては君 て相よ居在山つ言、獨、 兴、なくるでせた制ある逸私

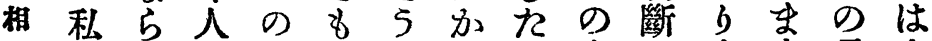

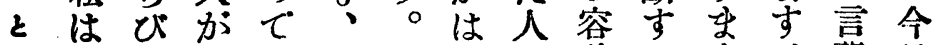
人乙に言、骨西知召貌るす寸、葉日

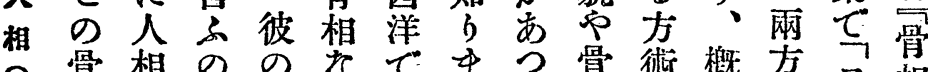
富骨相の のなでせて骨術概方フ 相

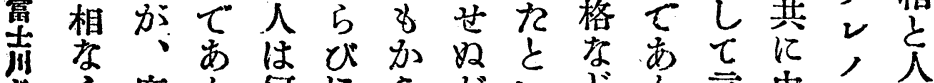

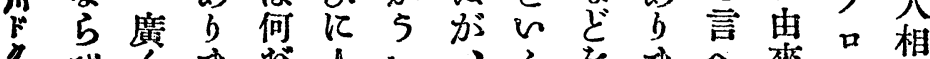

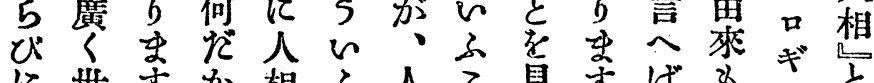

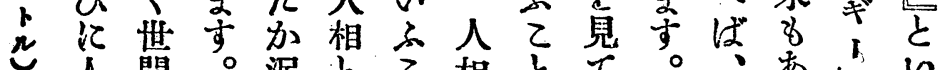

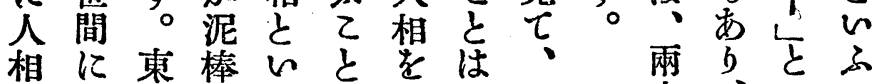

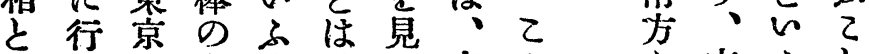
いはなな

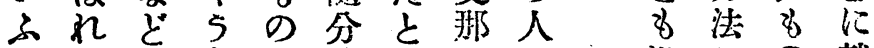

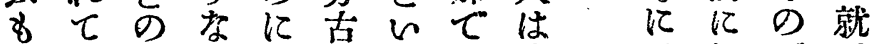
の居所顏就的ふは後

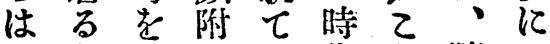
、相でて 、之㐫は代を隨え文體は人御 我いるし方ほ分ら相話

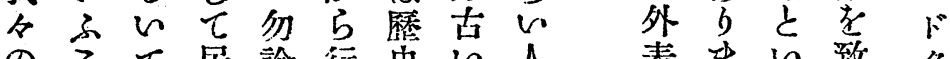
の之て居論行象的人表少心致》

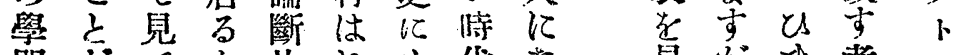

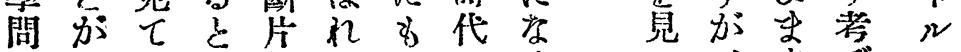

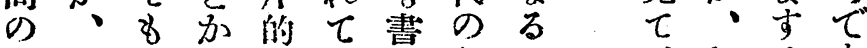

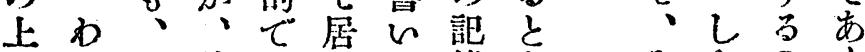

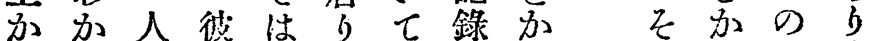
らる相の市むむに、 芫の の 效 b す てで看はま㩐 ああ版畕守我とてに $=$ 占は相分帮吉居な

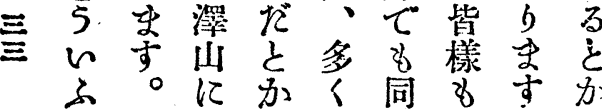

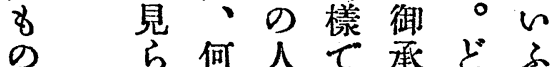
て れ あるかはらの的5 机儿は富 加要年守

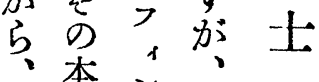
そ態オ悡川 人同, 骨 の 一三相

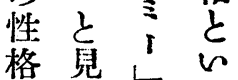

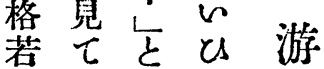
$\begin{array}{llll}L & 5 & w & d \\ & 3 & \delta & \Phi\end{array}$

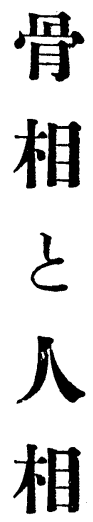
るの蚊、东事及な 


\section{$\sim$ 話 講}

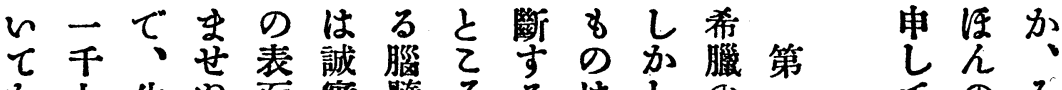

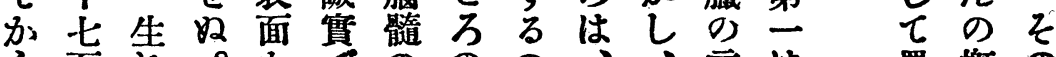

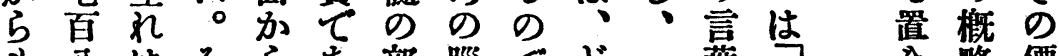

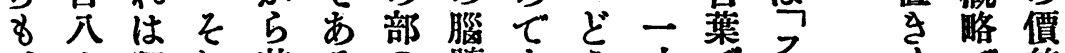

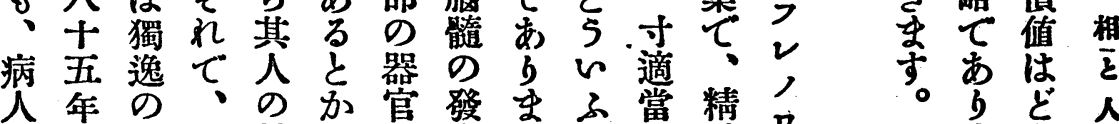

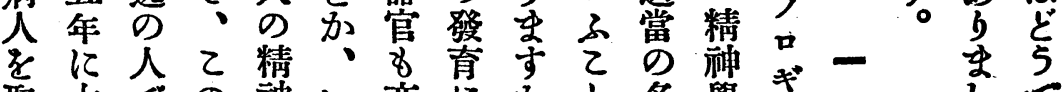

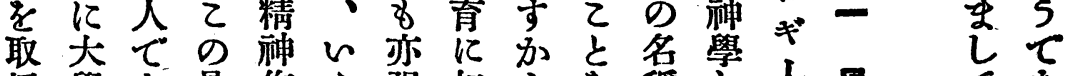

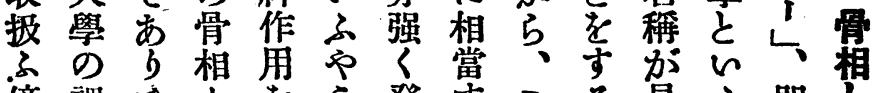

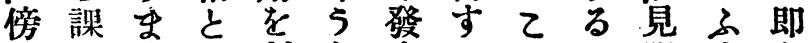

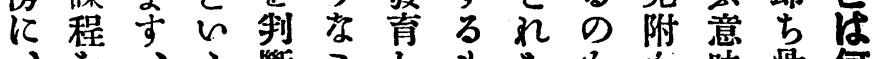

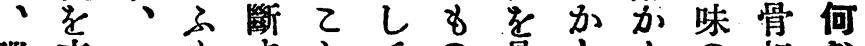

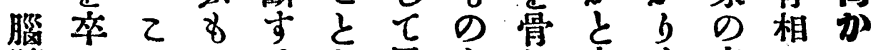

七索

鑂人ののるを居と相审玉字の

○て人をて制了しとしせ加事

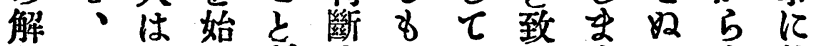

部下大加与口、守出就

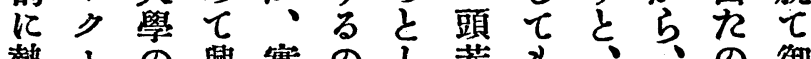

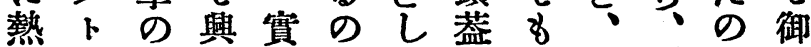

中學し際てて美頭假て話

しの生れにあ、表支蓋にあ几

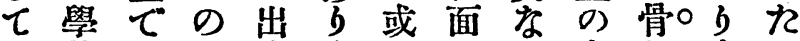

、位あは來生はの表相生し

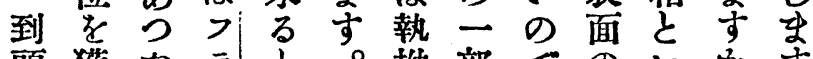

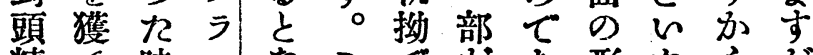

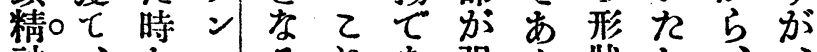

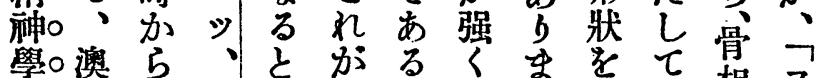

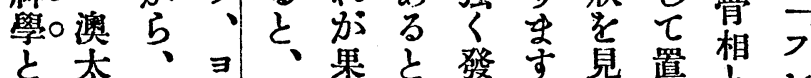

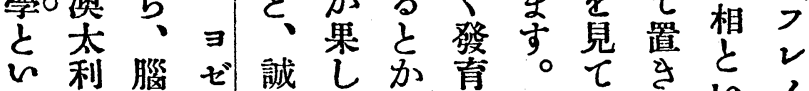

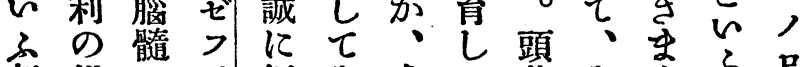

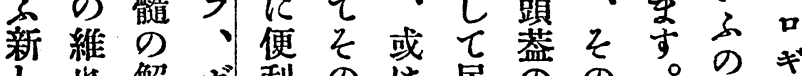

し世解刃利のは居のの。利

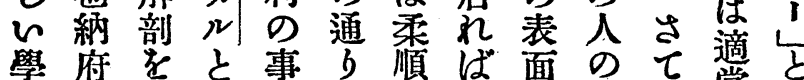

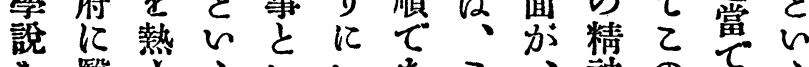

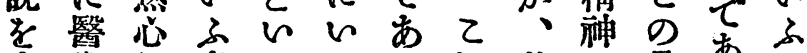

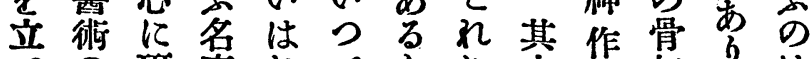

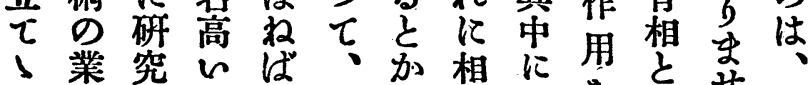

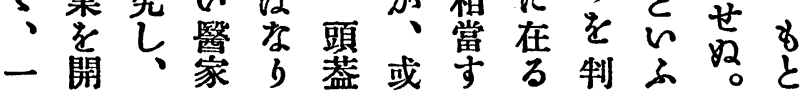

或务管

は 之

御

D 2

加 2

b

に

芺

12 略

\%

5 in

索名

事 5

名

あ 御

万話

致

\& 2

知

見

\&

せ 5

将息

2 c

让客西

は守

像

ぬ

御 固

断 


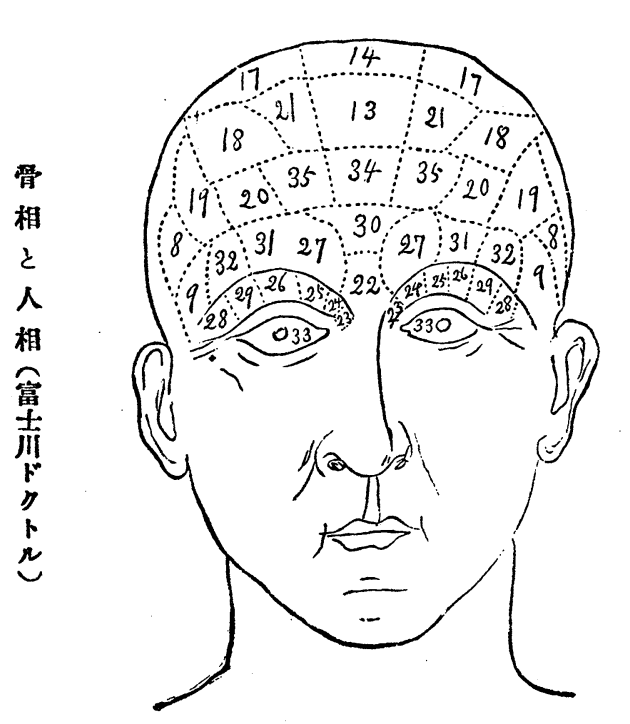

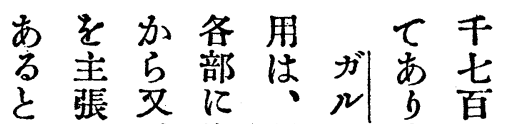

しし、配種はま杂

之た。腦置各前す立

と當各占各に年

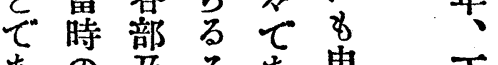

あの居あ打

つ說 びするて 度

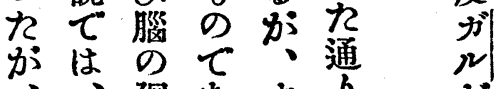

、廻あす方市

ガ頭轉るべ學年

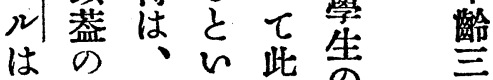

乙. 形頭 万等 品 干

$の$ 狀 荅說 の時厹

說とのを精柋藏

に公外唱神吕可

反了面全作 占時

器にて部れれ勝とて對多にれ用授に

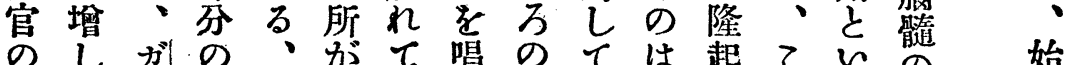

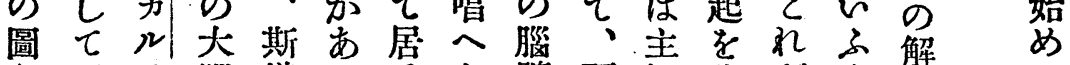

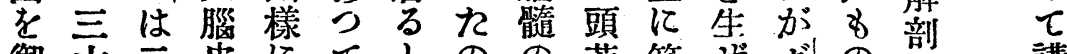

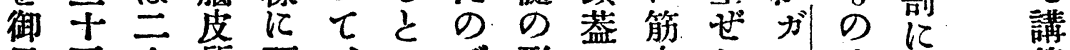

目五十質頭、的で形の肉しルは心延

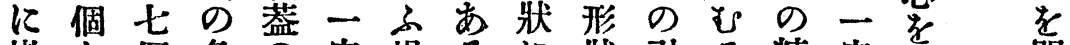

掛と個各の定場るに牀引る精定傾 開

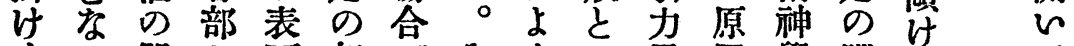

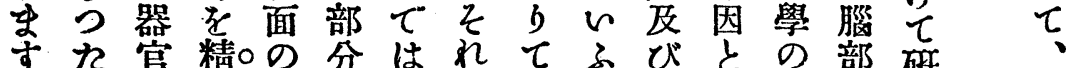

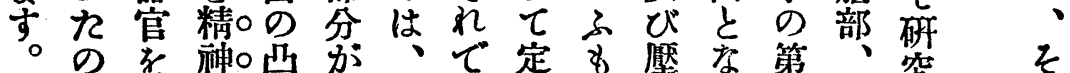

て記の出凸之、告の力方即究少

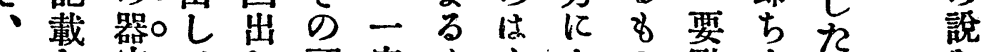

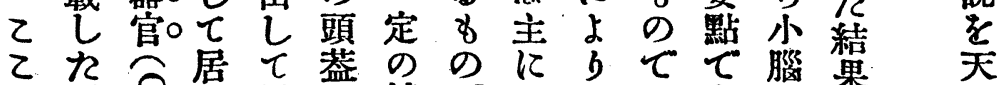

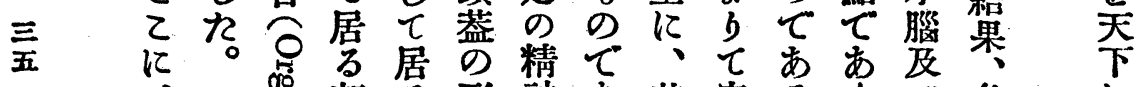

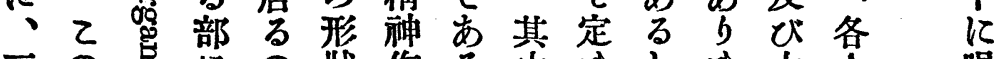

三の江の牀作方中主之ま大人唱

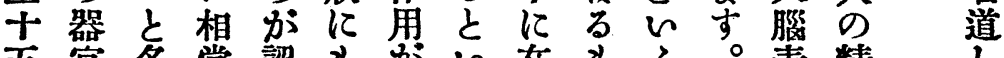

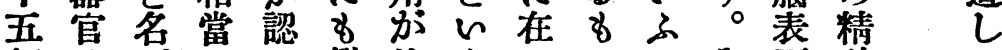

個はづせめ變他々るの之そ面触え

の後けるらうにてとてとれの作のの 
醫 れの具女部腦の

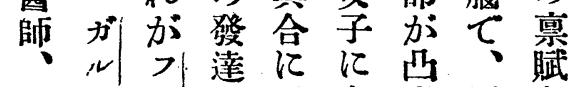
醫はラの、在出圖壱 學 、 具 精 3 乙 中 制 生乙 をの、はのは居 1 主 始學妇、作、设とる

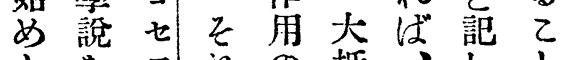

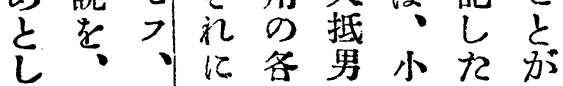
七一皮相個思兒所出 、千當によ索怔 呚七の守就 $b$ 愛々古

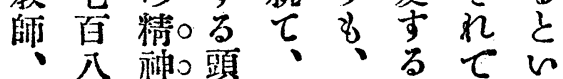
官十學。蓋別乙のあ市

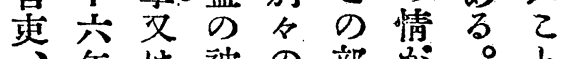

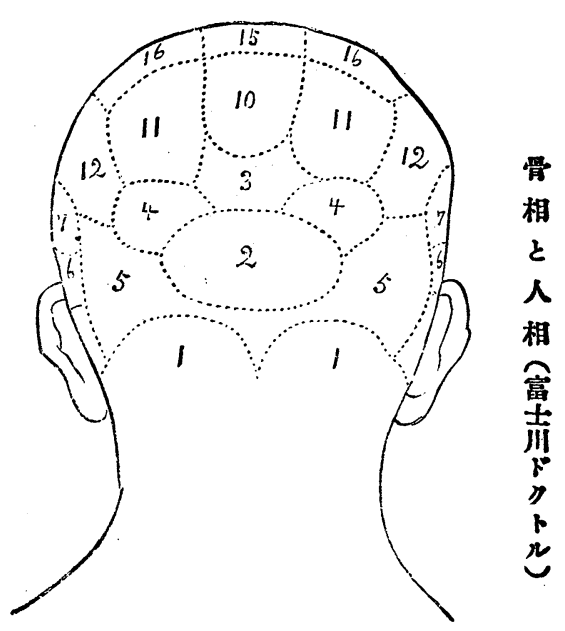

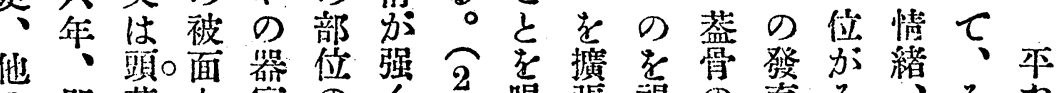

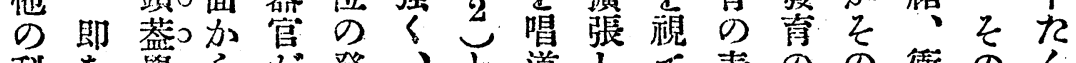

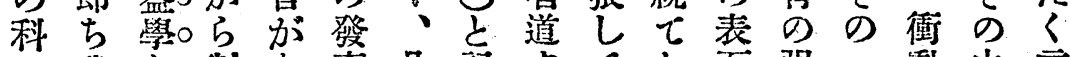

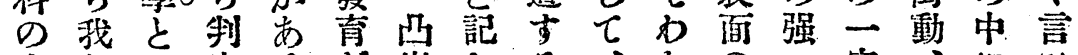

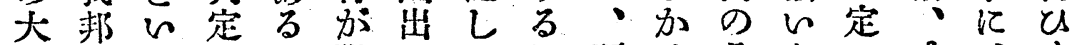

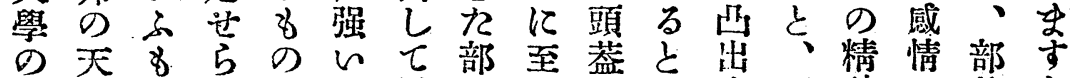

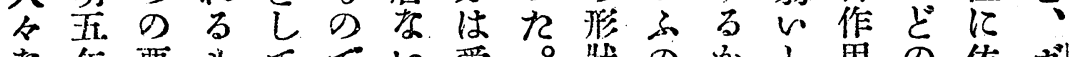

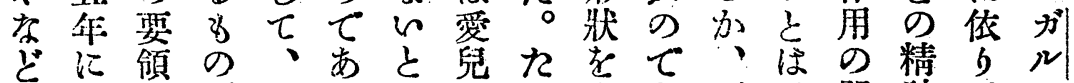

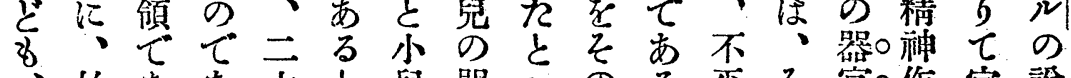
、始ああ十と兒器へのる本そ官作官說

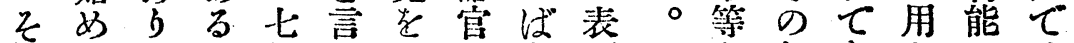
のてぬと個つ愛に色面乙な部市加のは

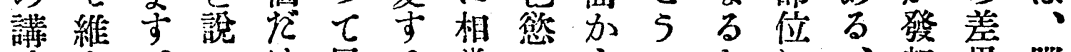

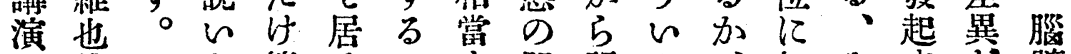

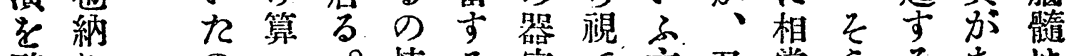

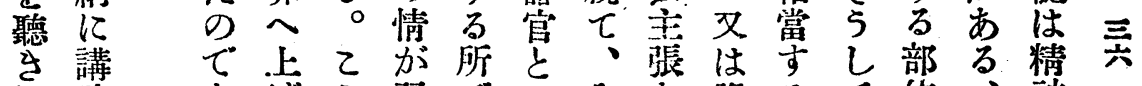

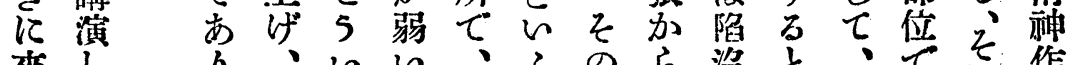

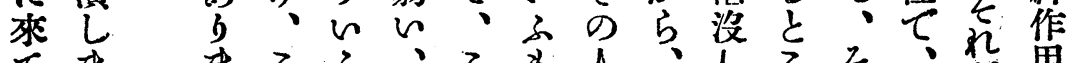

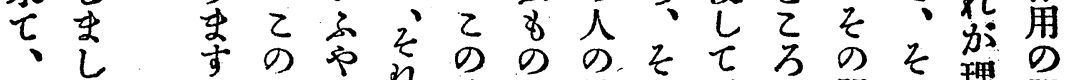
隨れ。器 5 れ後は精の居の器の理器 分分乙官なて頭小神說当頭管部性官 


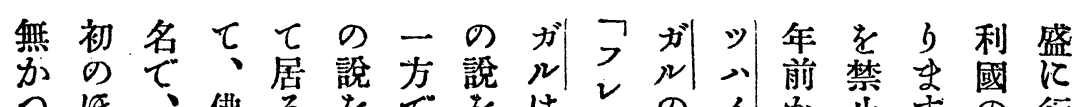

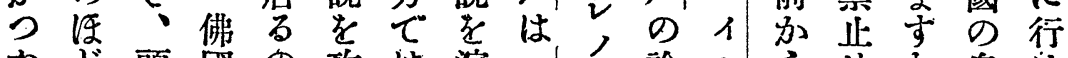

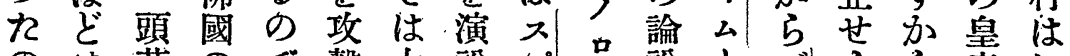

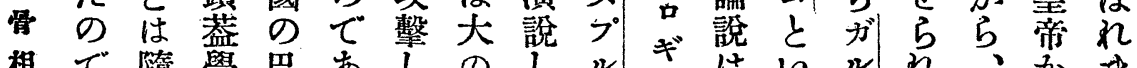

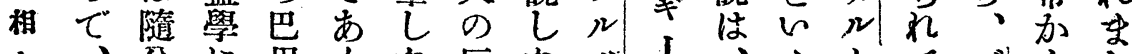

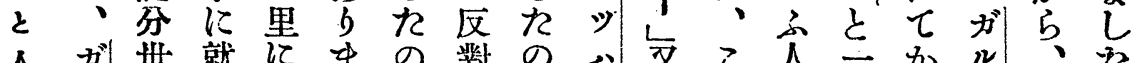

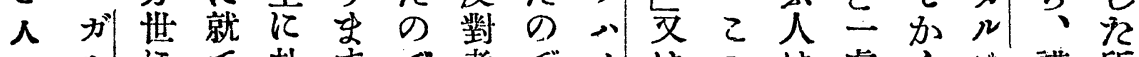
相㞦飞赴守て者でイはのは處らは講所

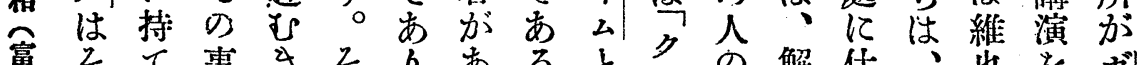

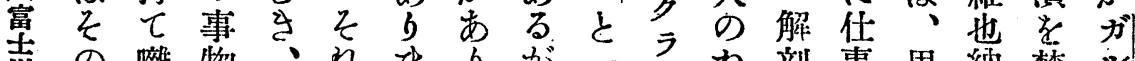

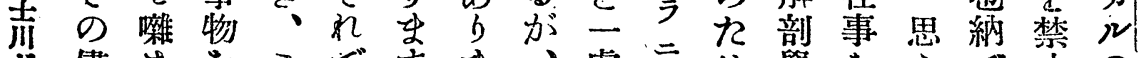

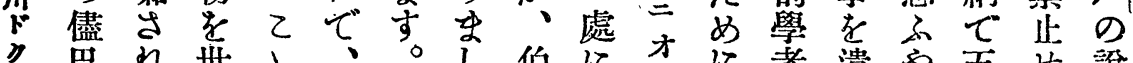

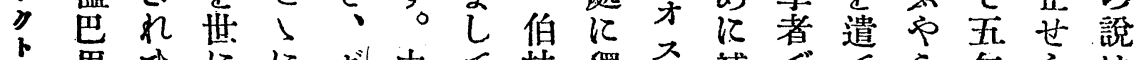

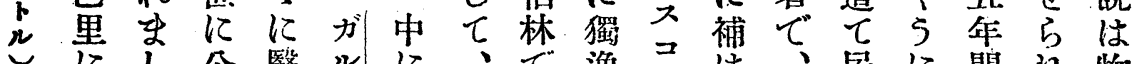
飞公敔江飞、て逸飞は、居に間れ物

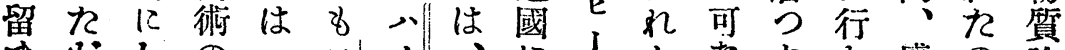

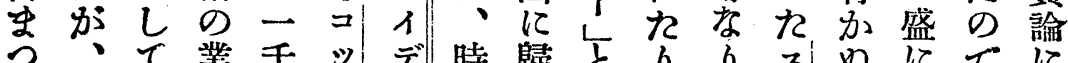

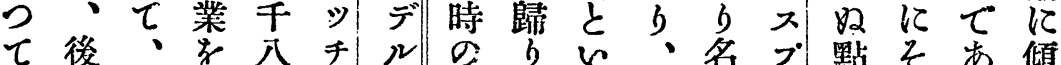

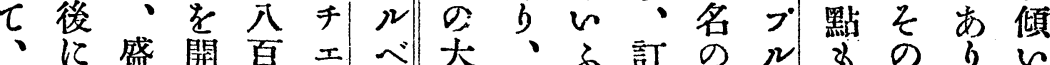

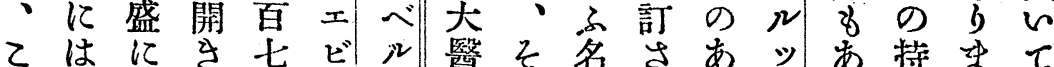

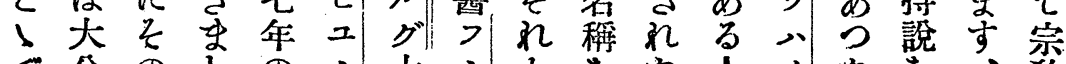

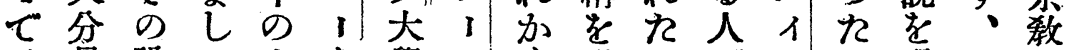

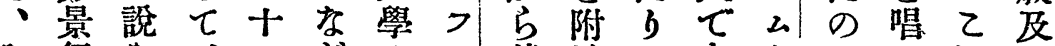

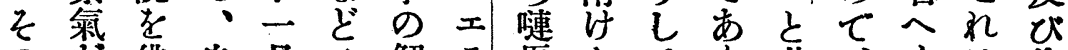

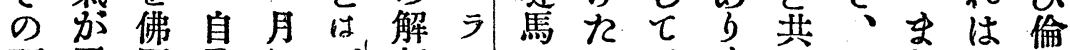

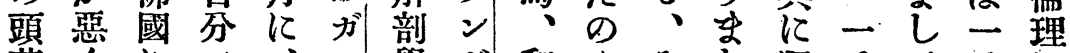

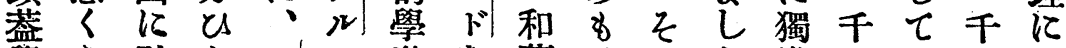

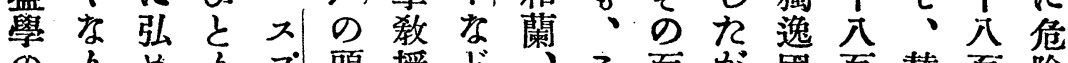

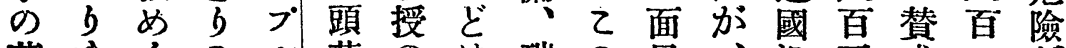

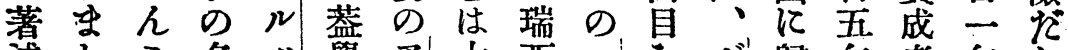

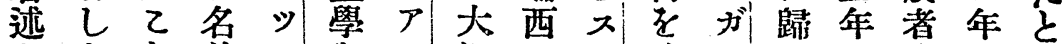

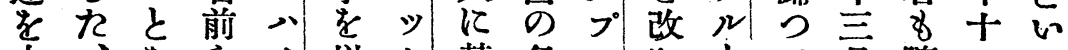

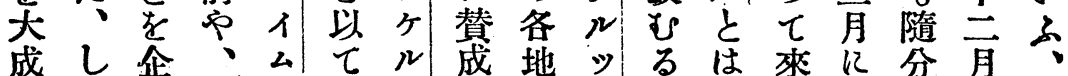

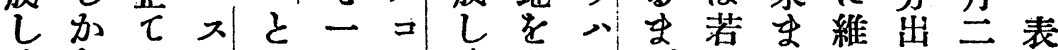

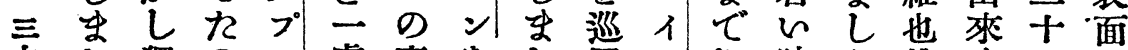

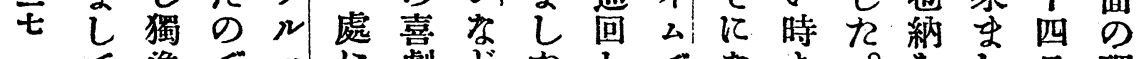

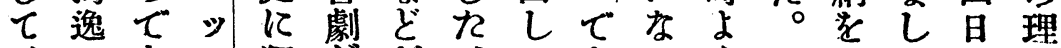

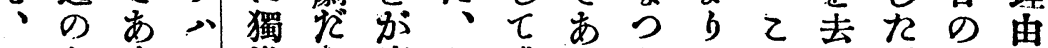

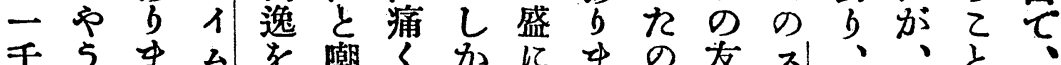

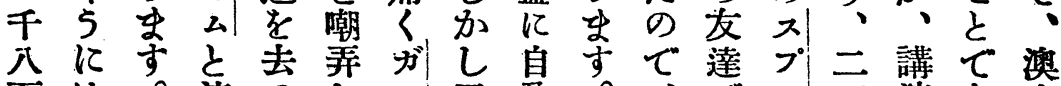

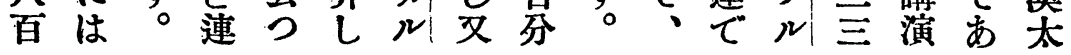


の學

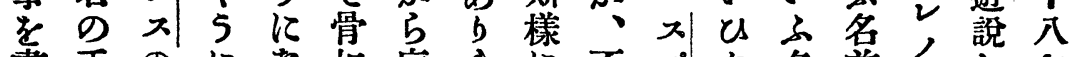
書手のに相怠ま否プ 名前口し年

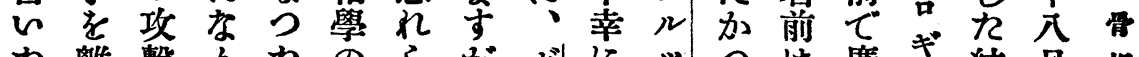

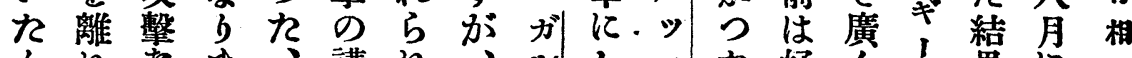

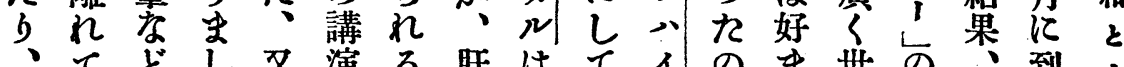

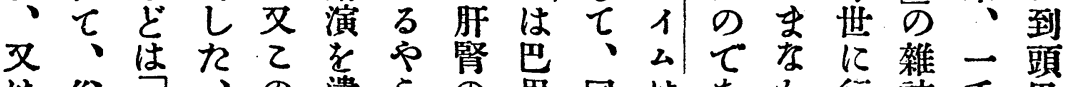
は俗子、の遣５の里同はあ加誌千暨

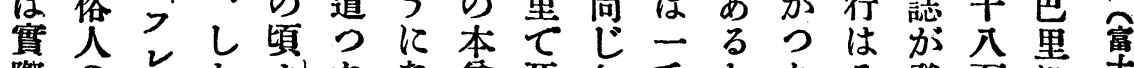

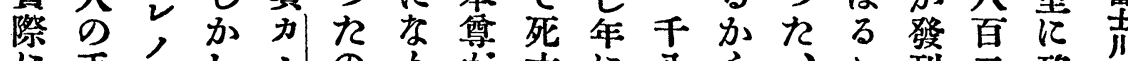

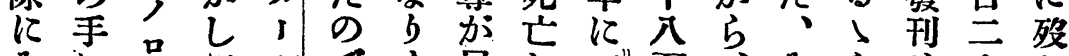

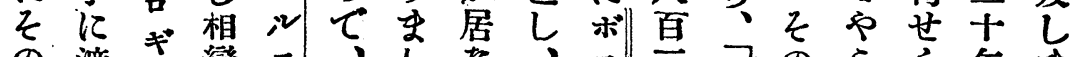
事渡筱

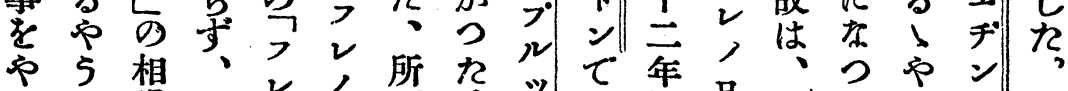

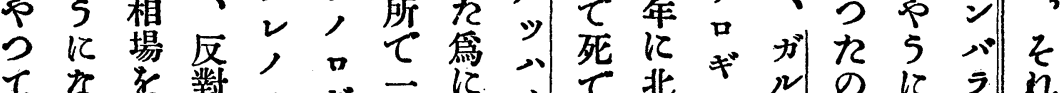

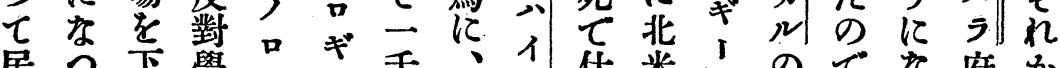

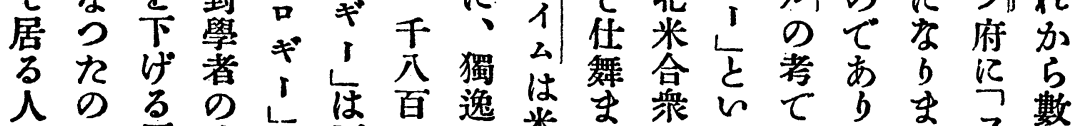

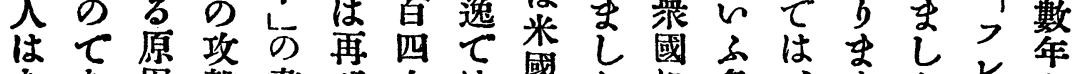

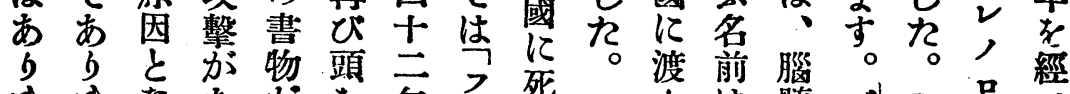

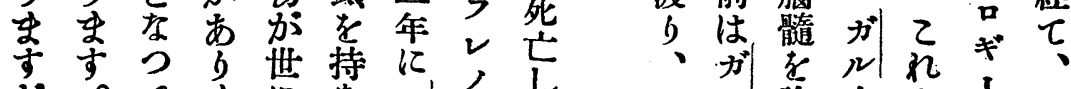

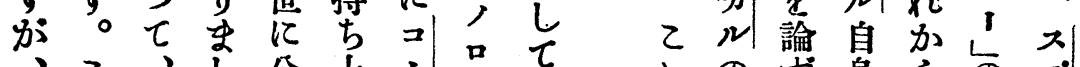

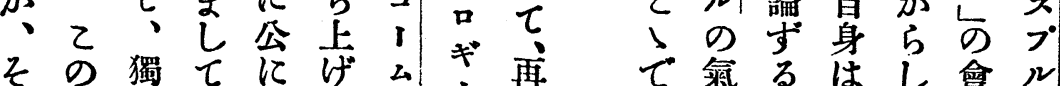

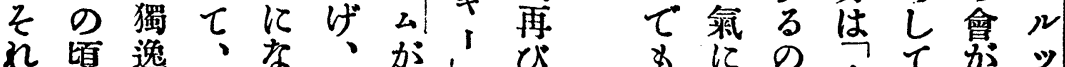

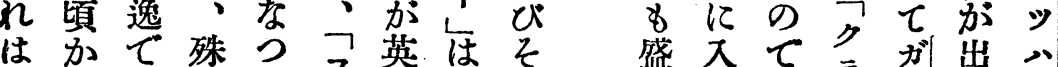

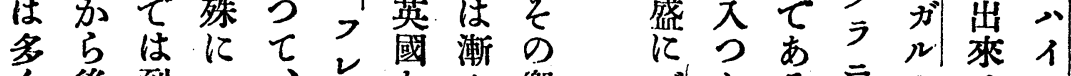

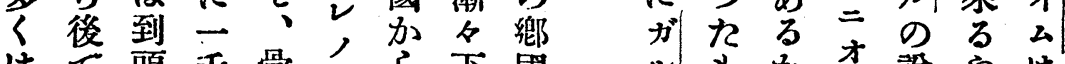

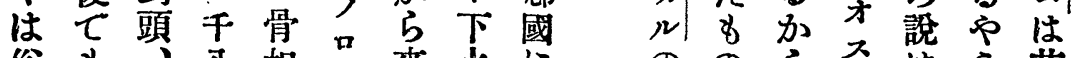

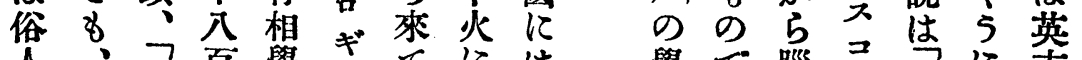

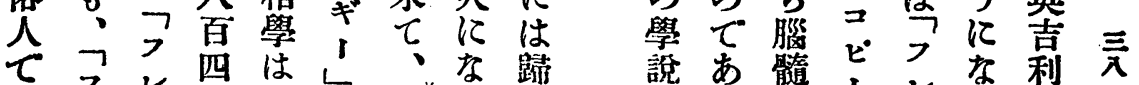

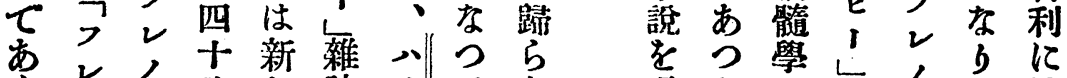

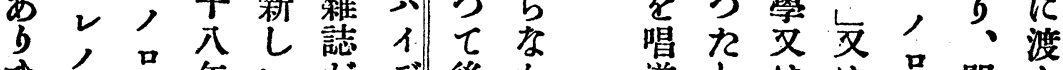

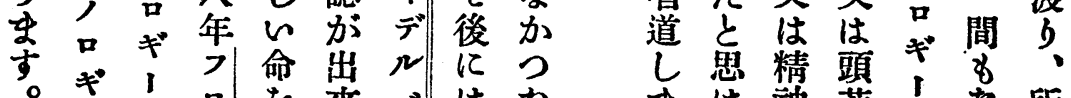

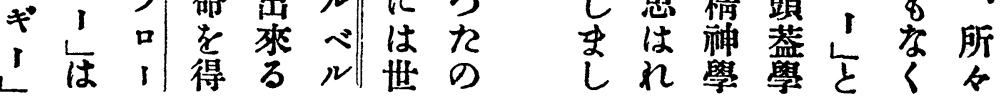




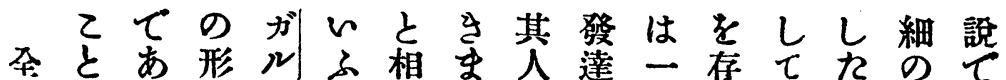

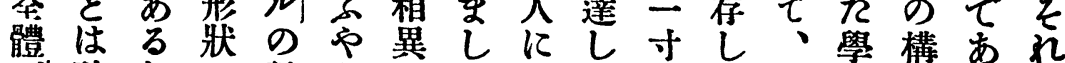

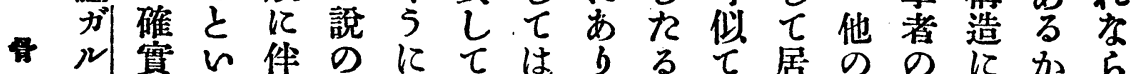

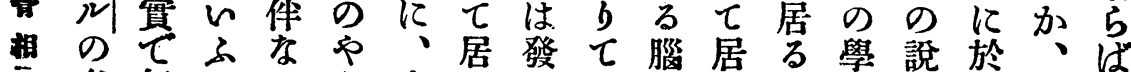

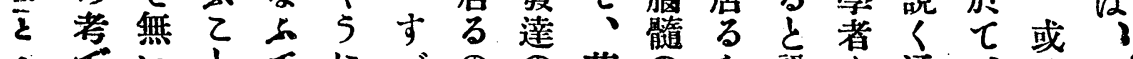

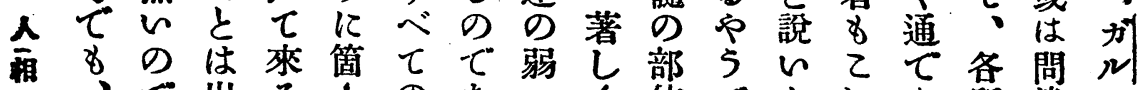

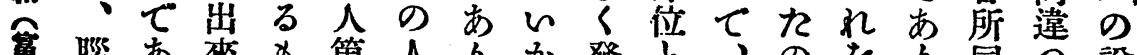

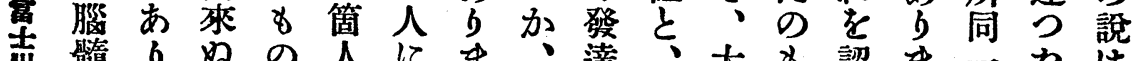

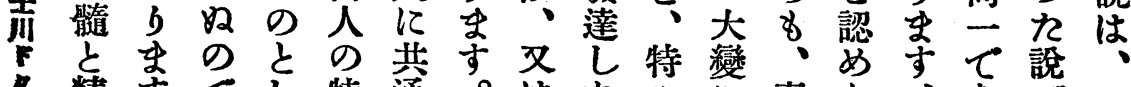

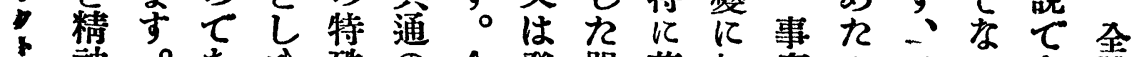
神。市殊の今發器著相曾の及心市䣓

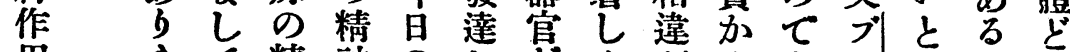

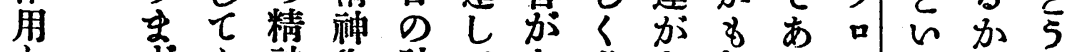

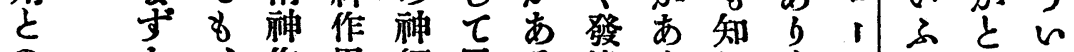

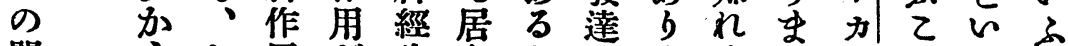

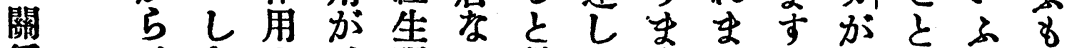

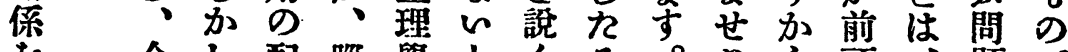

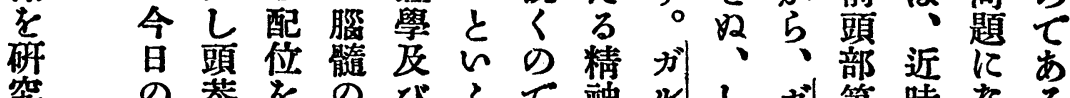
究の㿽をのび々て神仙しが第時なる

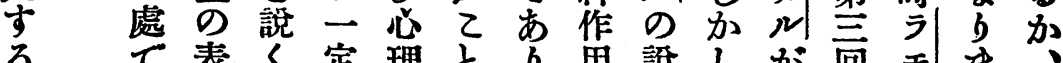

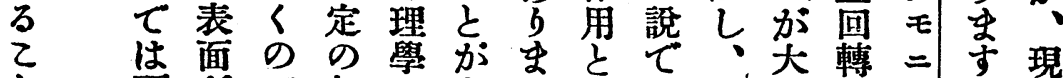

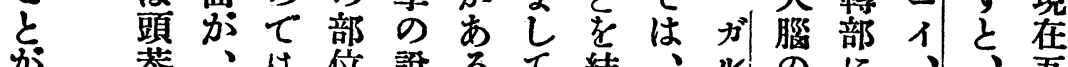

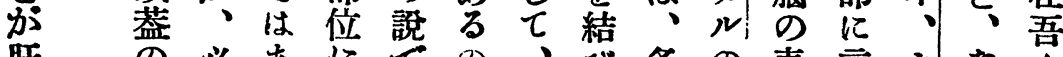

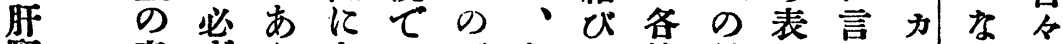

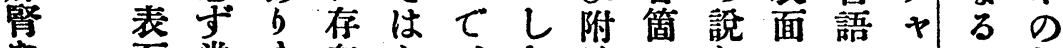

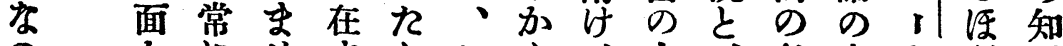

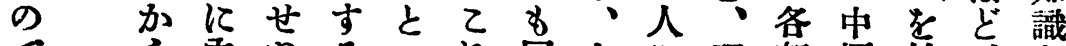

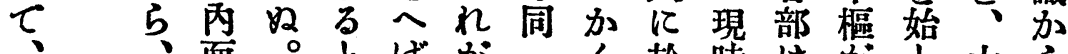

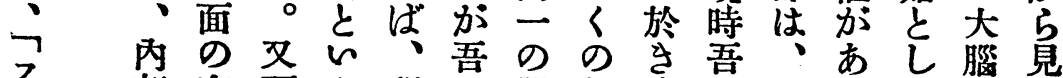

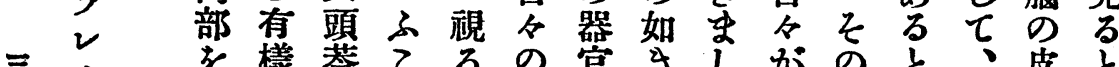

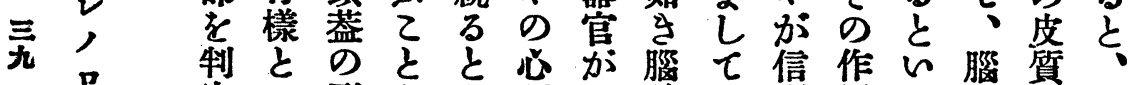

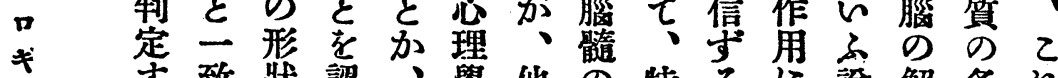

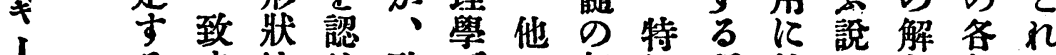

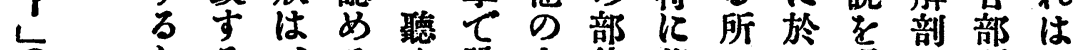

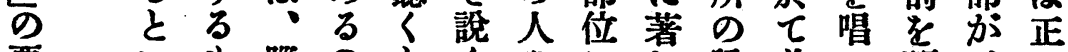

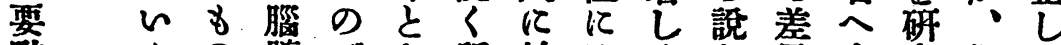
點々の嗵て吕所於はく異生究微的 


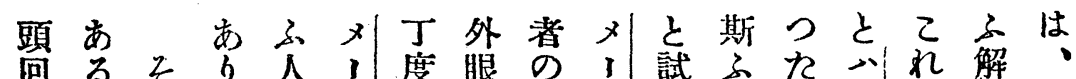

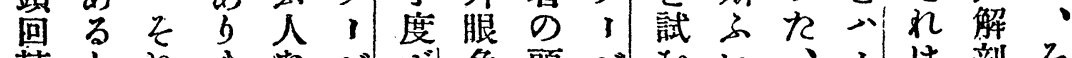

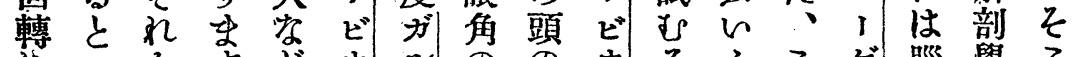

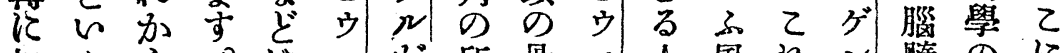

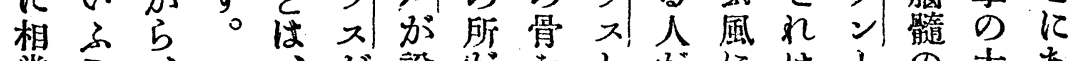

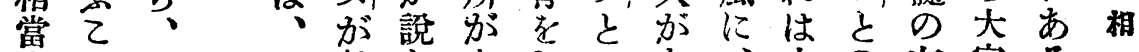

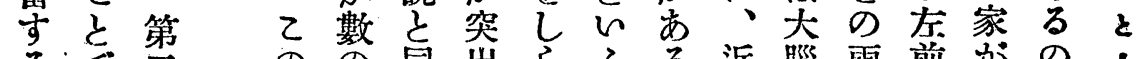

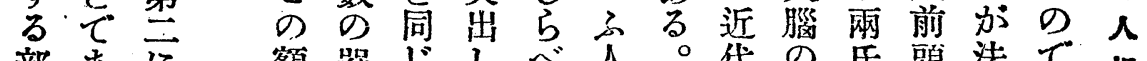

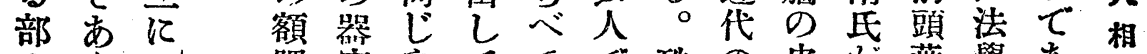

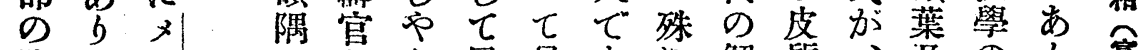

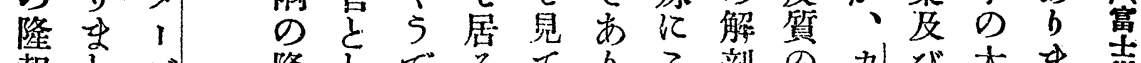
起し 苦て、著 荖大怒

く音主 發樂張 育家 ᄂ ᄂ $\rightarrow$ $\tau$ 1.

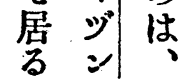
多心意

認 1 亿

め䍡

万市能

社标

る

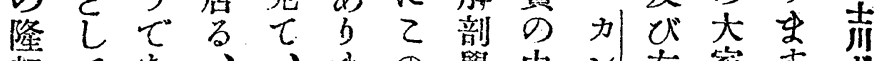

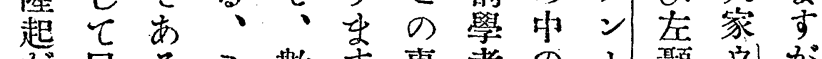

言

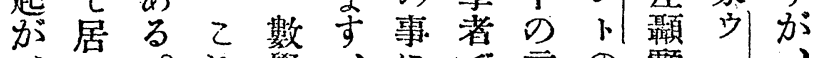

つバ頭

$\tau$, 签

居 㭛

可

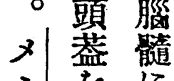

流

飞自は

光 特

ス 異

9 策

锐第變

は前常

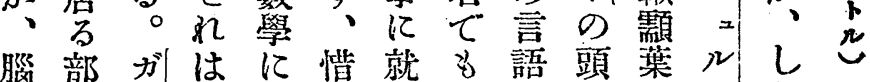

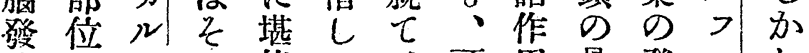

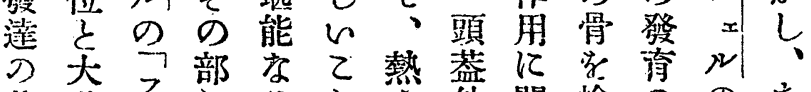

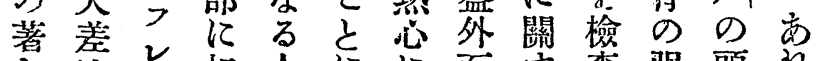
しは相人に面卞香强頭れ

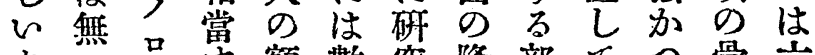

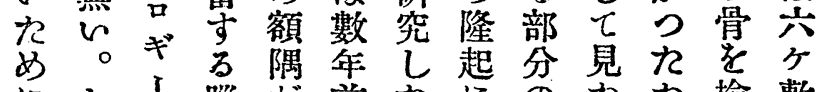

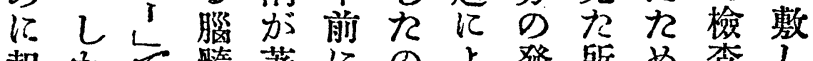

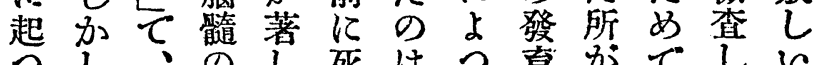
つしのし死はつ充加てしに

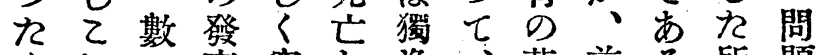

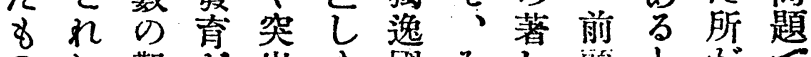

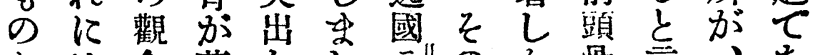
とは念著しし引加骨言市

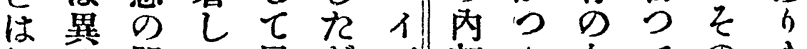

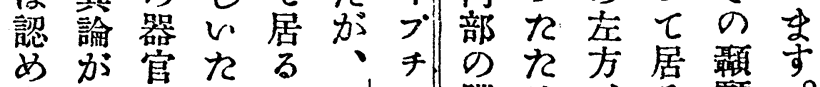

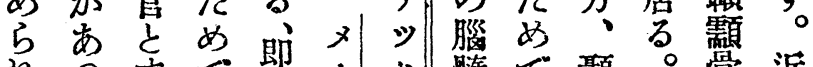

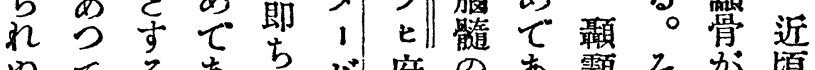

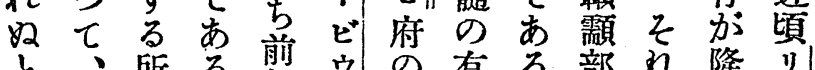

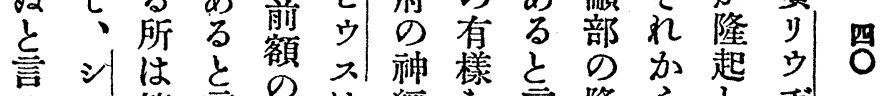




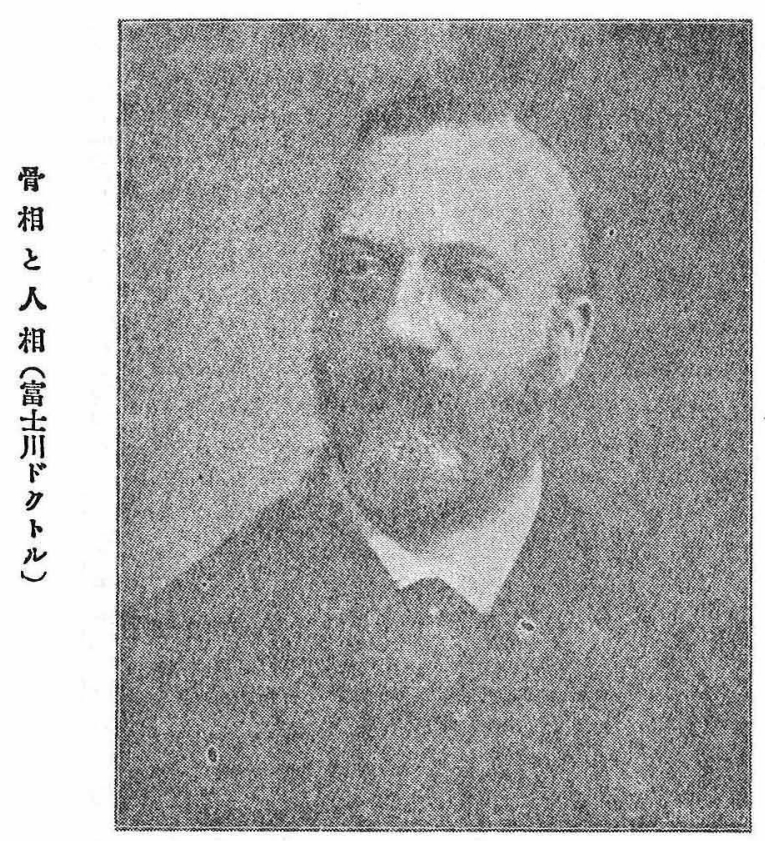

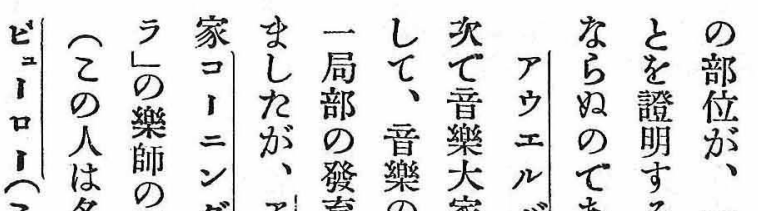

之名長グア筲萣バ

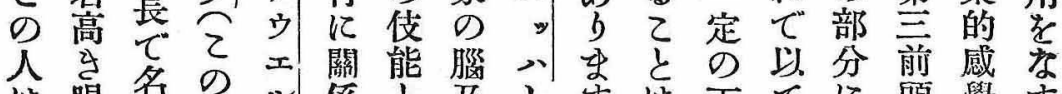

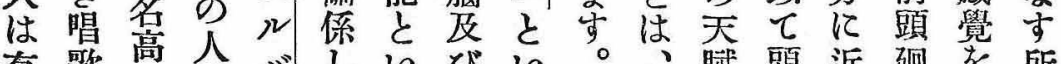

有歌高は 口大人

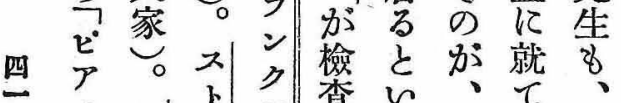

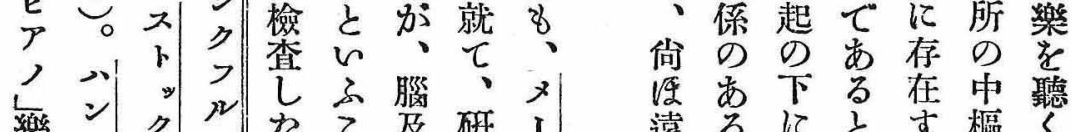

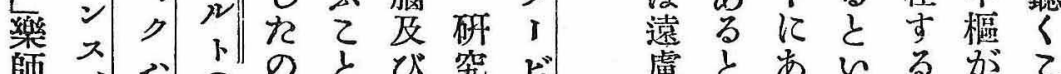

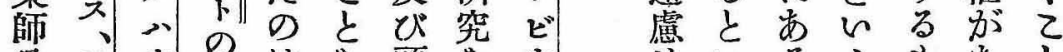
策 フ十

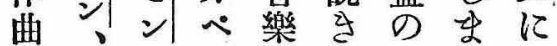

を曋樂腦 I 5 等步

ビ、創 制 中 はガ索覺 說 2 (

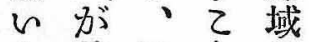

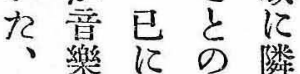

乙 加器学用 L ᄂ官记老て 之多总䙷居 れづ樂る部 に存的分 \&) $て$ 再 糜居告意 の所るる樂 論 98 的 か子务 の

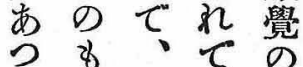
$\tau 大 乙$ 別受 抵れ湟 乙乙㬜作 ば々粗とでて音

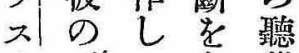




\section{話 講—}

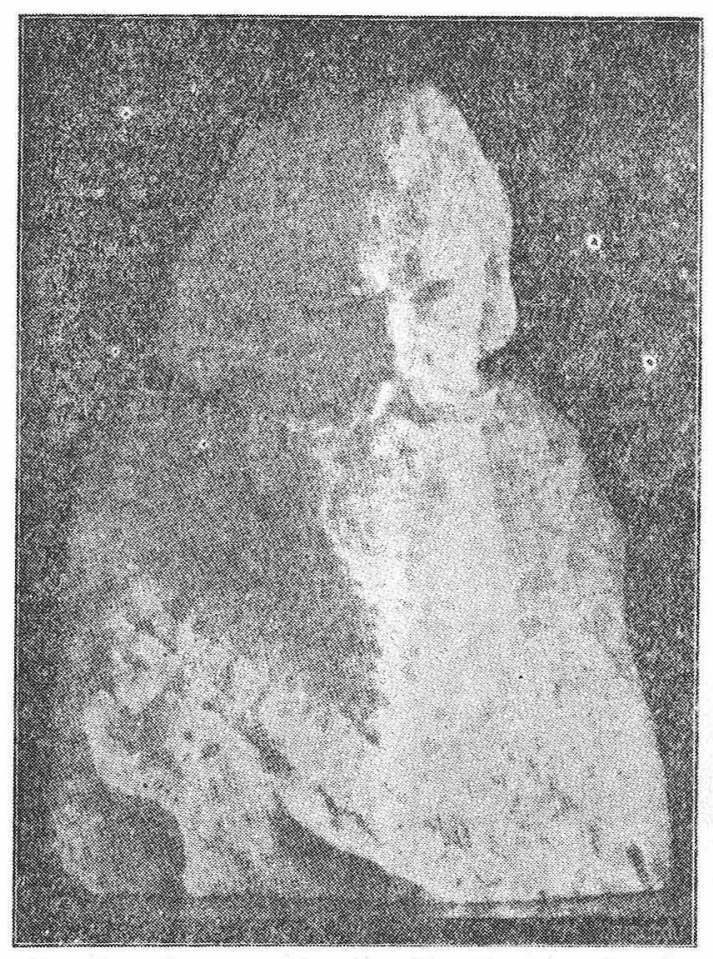

$$
\begin{aligned}
& \text { 出出 ᄀ它家 }
\end{aligned}
$$

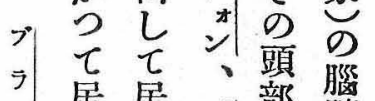

$$
\begin{aligned}
& \text { 居居ビ| 部䯣 }
\end{aligned}
$$

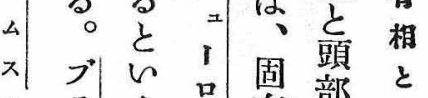

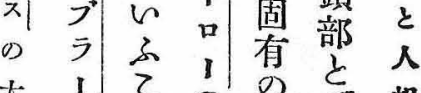

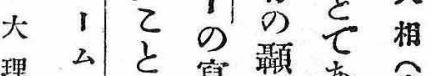

$$
\begin{aligned}
& \text { 石 スは舄霣 あ 富 } \\
& \text { と認は部れ壱 }
\end{aligned}
$$

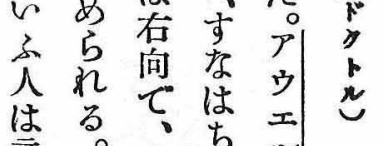

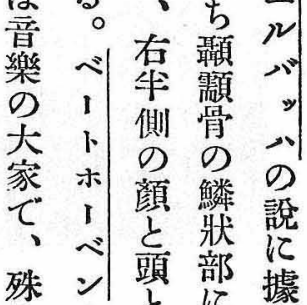

$$
\begin{aligned}
& \text { にの と坨 } \\
& \text { 作頭㠰想當 } \\
& \text { 曲的見賞 }
\end{aligned}
$$

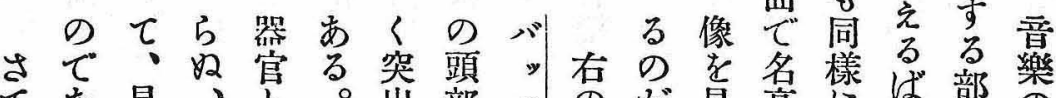

$$
\begin{aligned}
& \text { 頭。年及名ししてはや随る心固方位大 }
\end{aligned}
$$

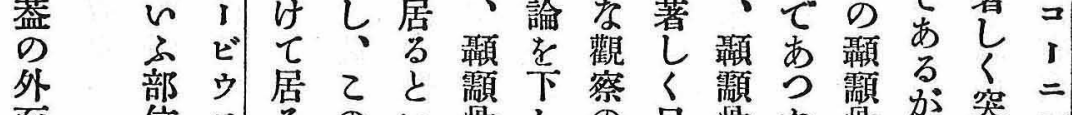

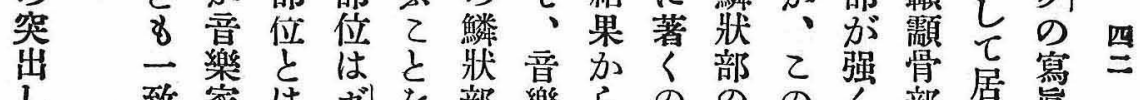

$$
\begin{aligned}
& \text { 九しの }
\end{aligned}
$$

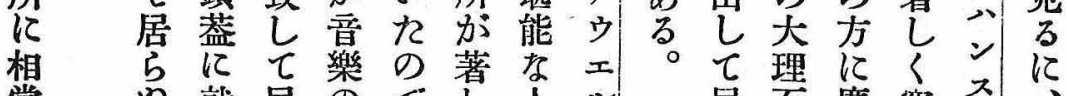

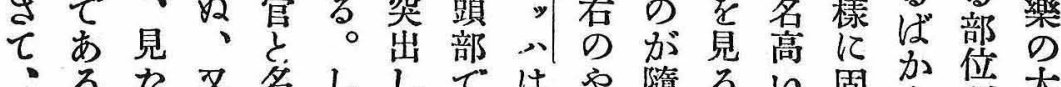

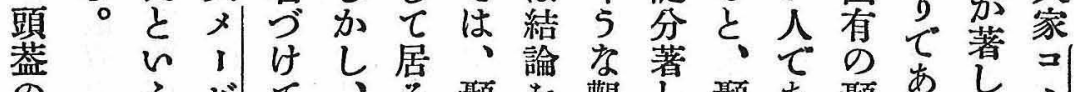

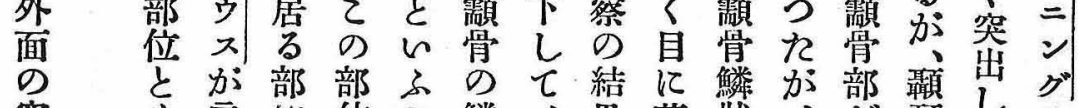

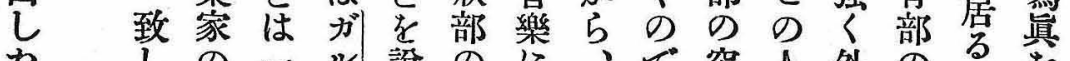

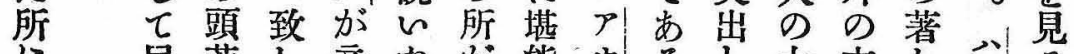$$
\text { 當就居口てし人心居石廣突元に }
$$ 

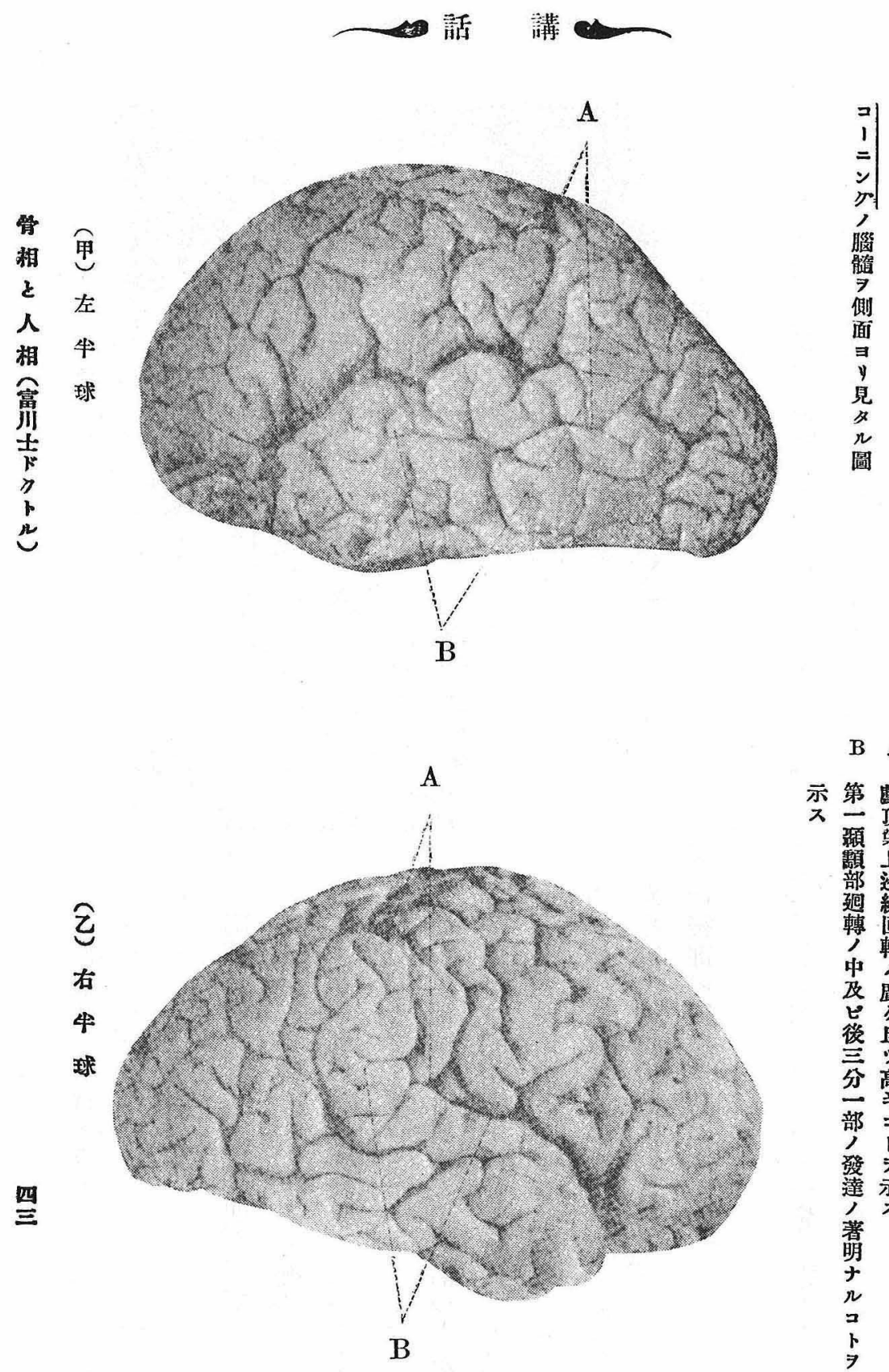

B A 示第

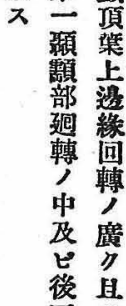
分高 部 被 達示

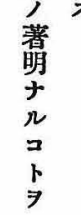


—話 㱐

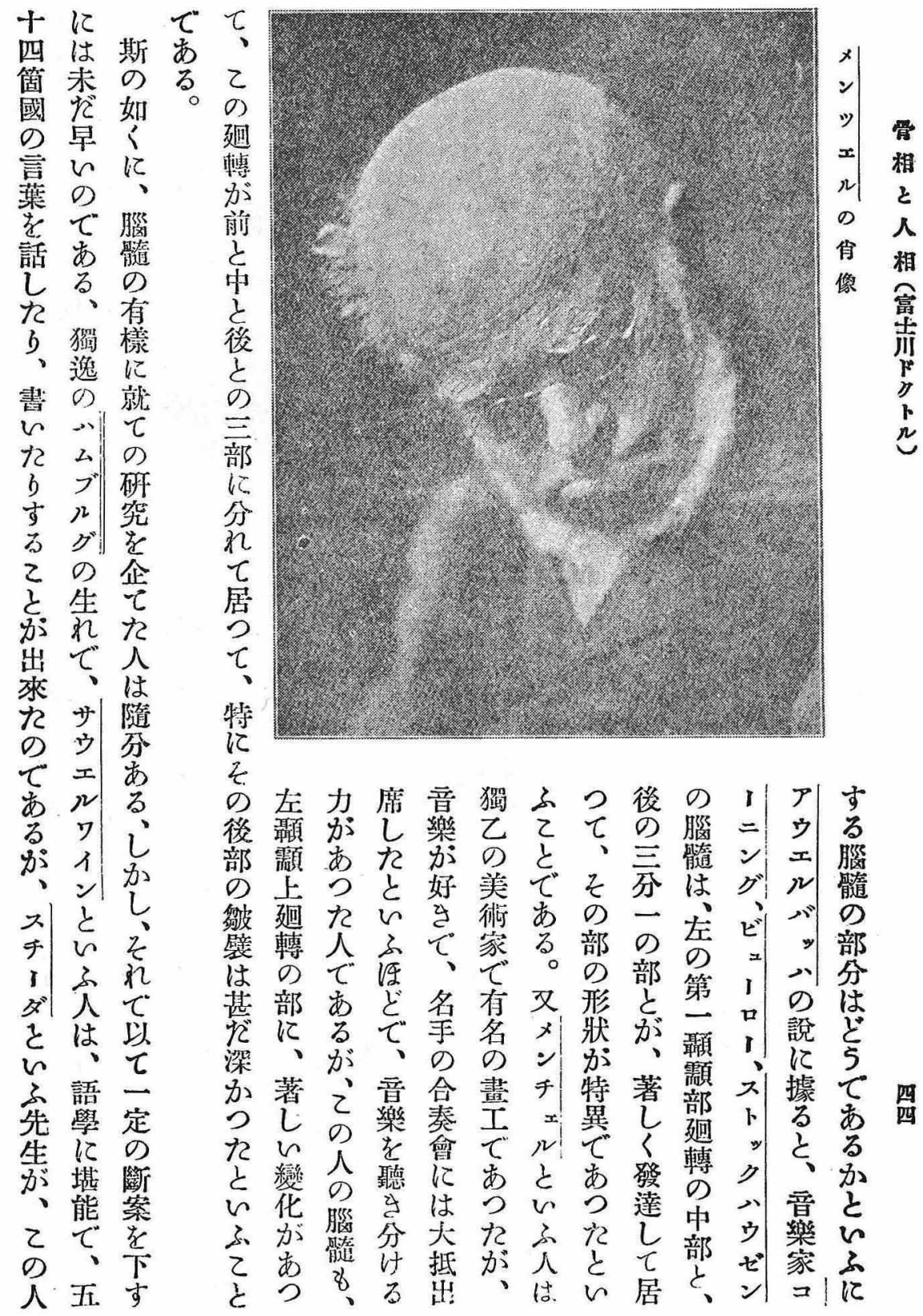




\section{م話 講}

づ焚或す邓ラノりあ定て制てつの

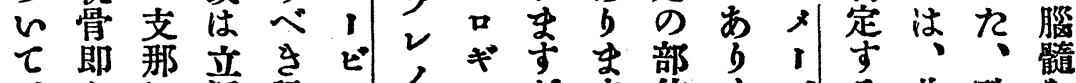

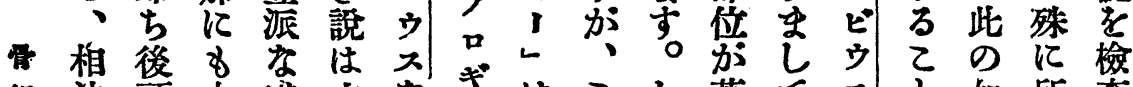

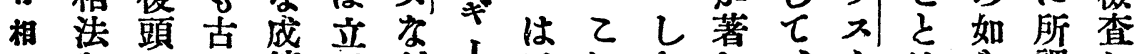

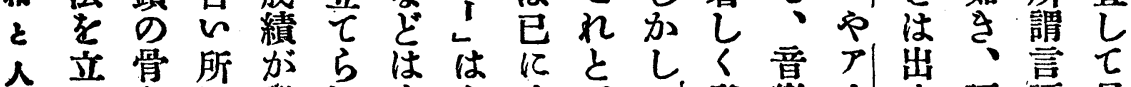

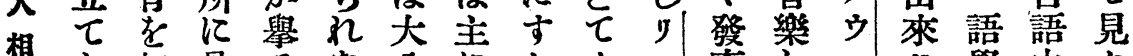

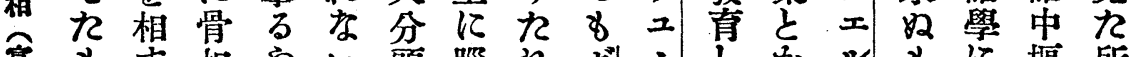

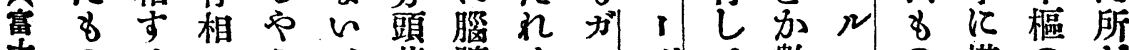

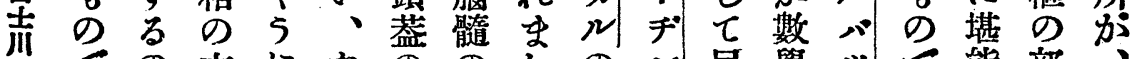
ץての文にれの のしのン居學ッて能部

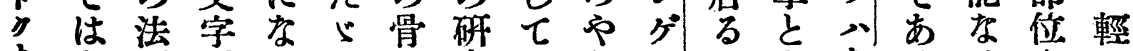

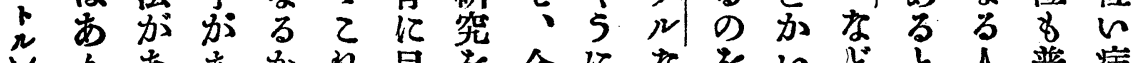

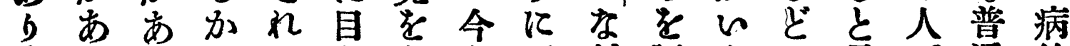

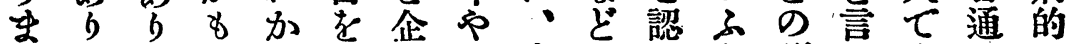

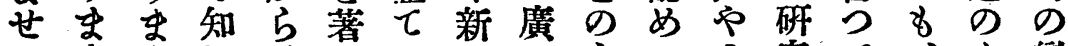

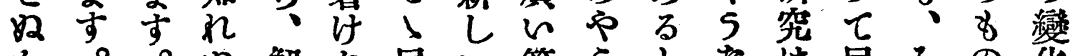

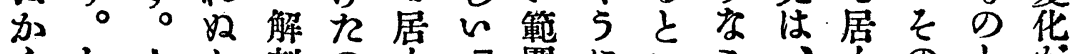

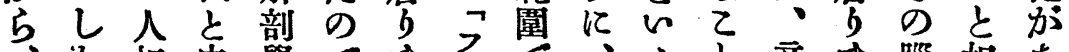

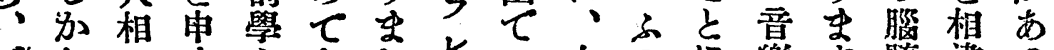

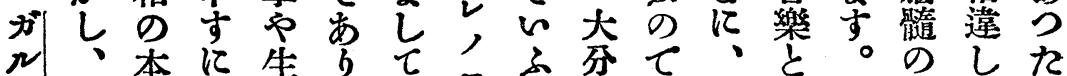

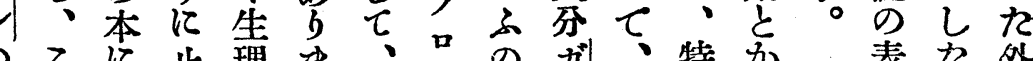

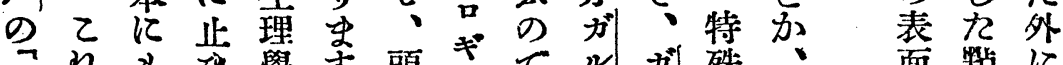

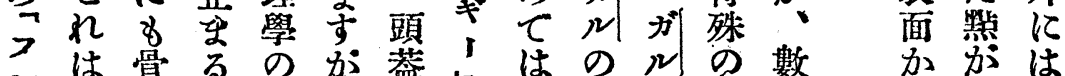

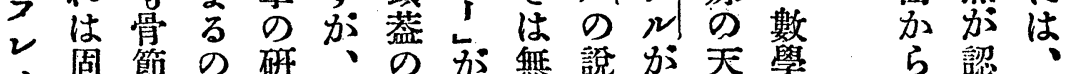

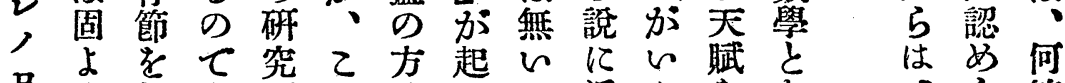

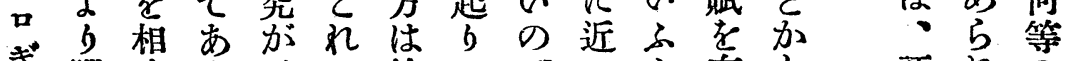

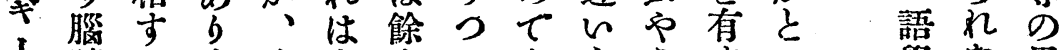

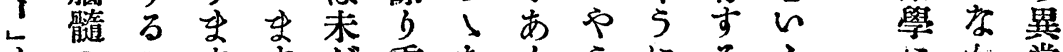

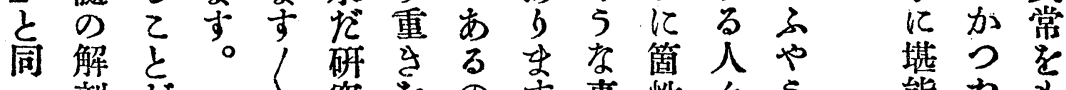

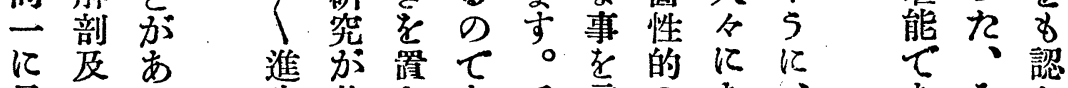

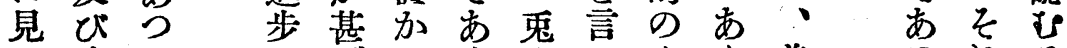

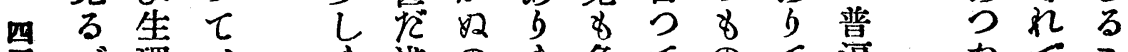

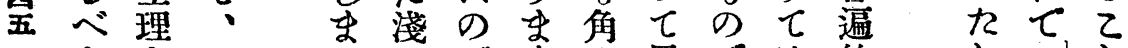

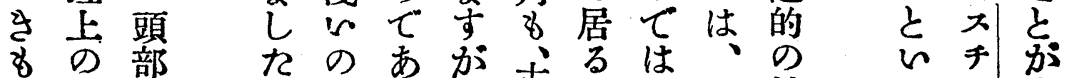

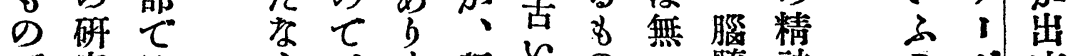

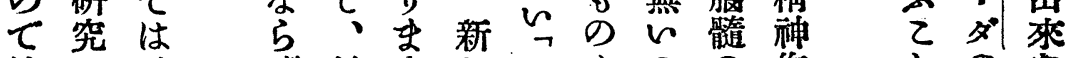

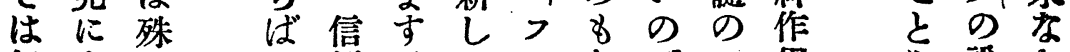

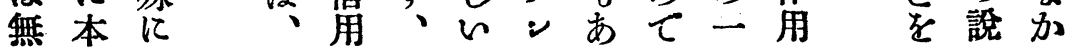




\section{$\sim$ 話 講}

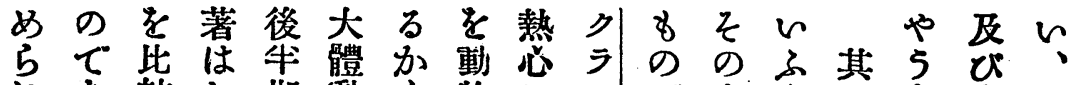

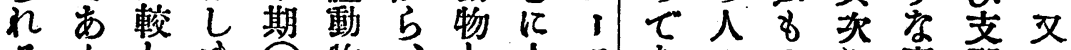

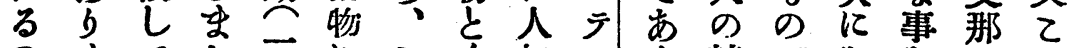

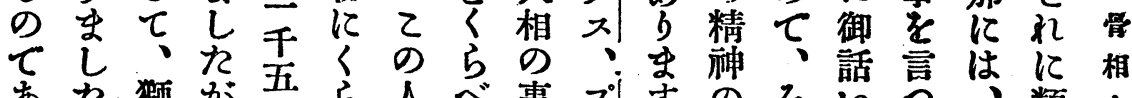

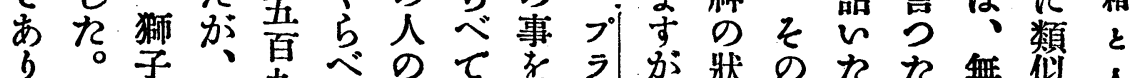

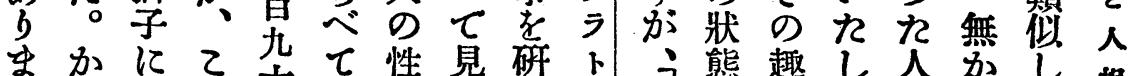

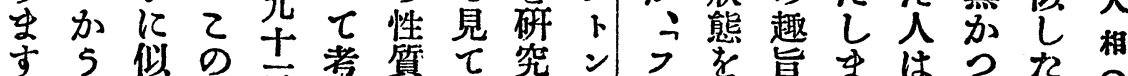

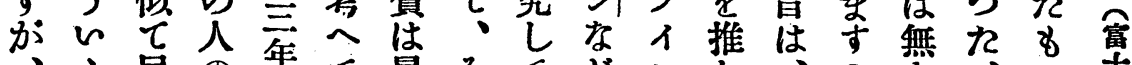
分居

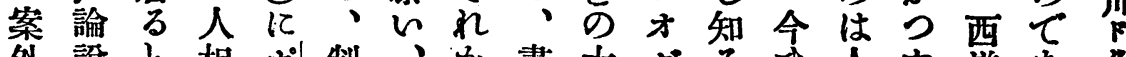
外説之相利制、加書太グるま人九洋市

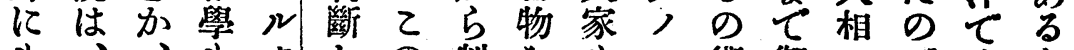

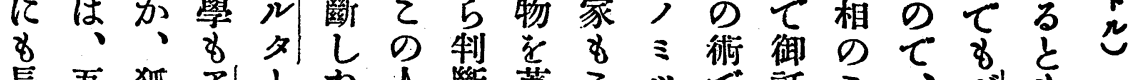

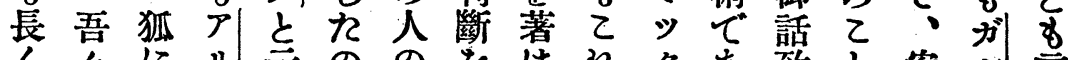

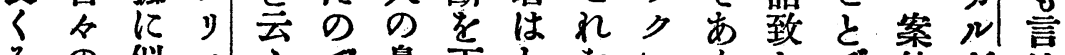

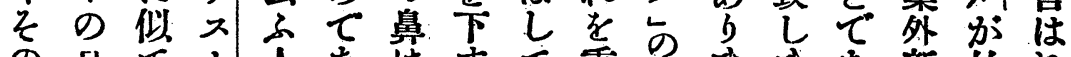

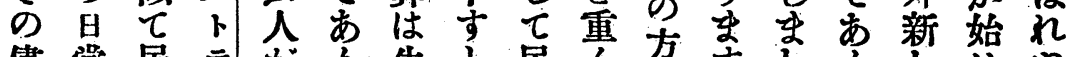

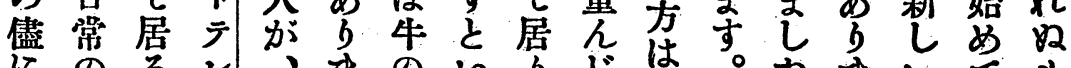

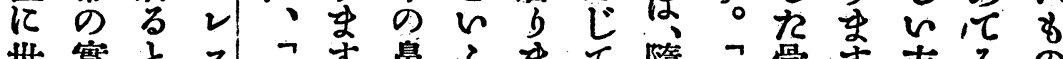

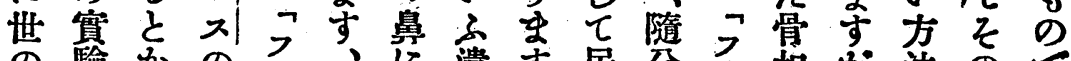

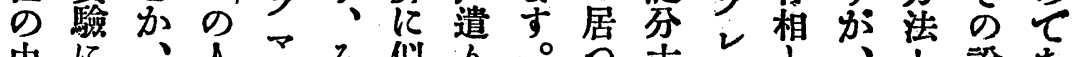

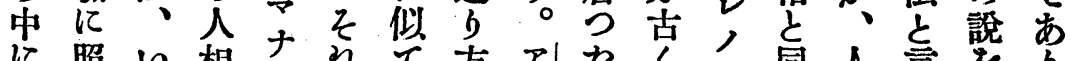

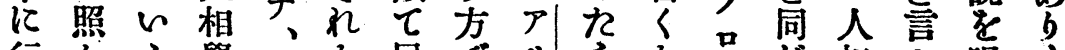

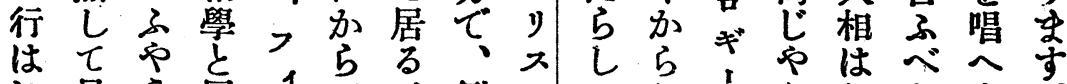

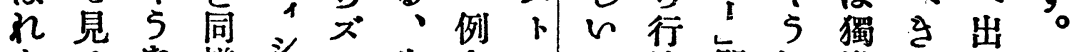

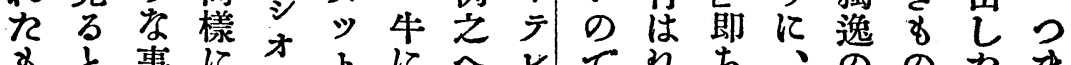

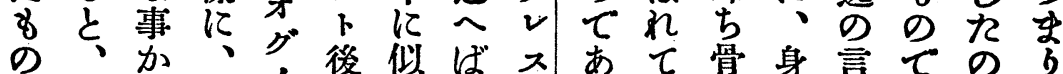

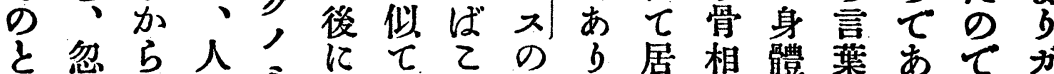

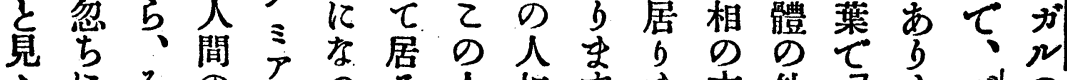

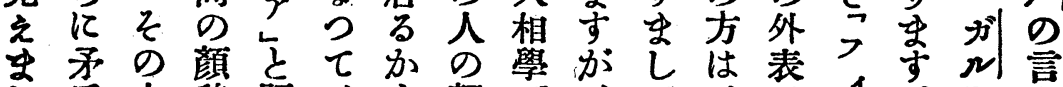

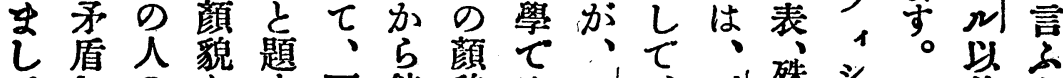

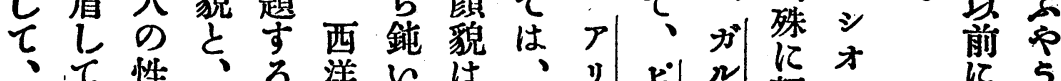

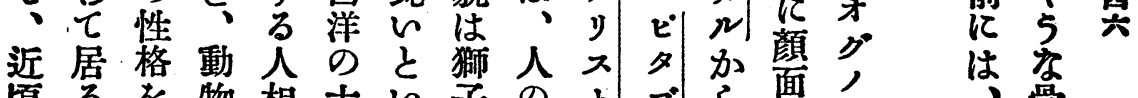

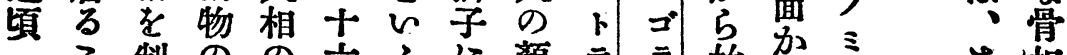

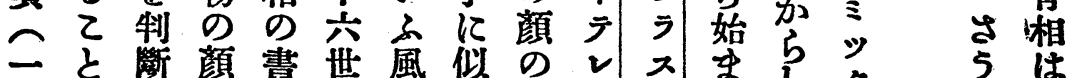

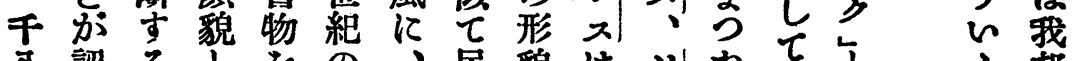

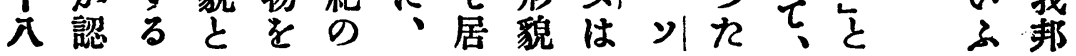




\section{$\sim$ 話 講}

居目

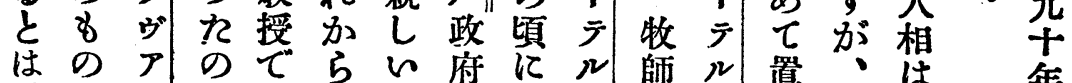
骨言年

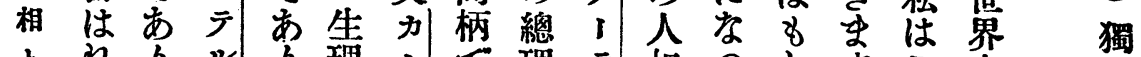

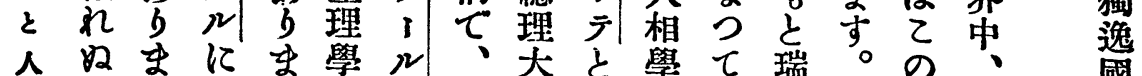

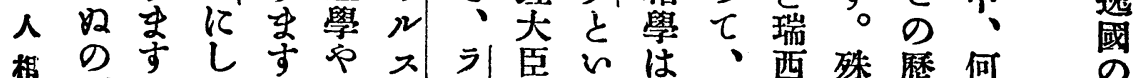

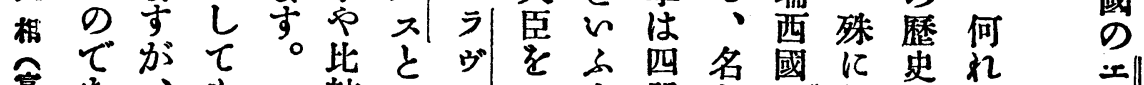

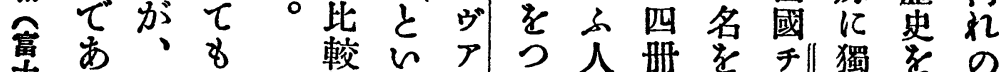

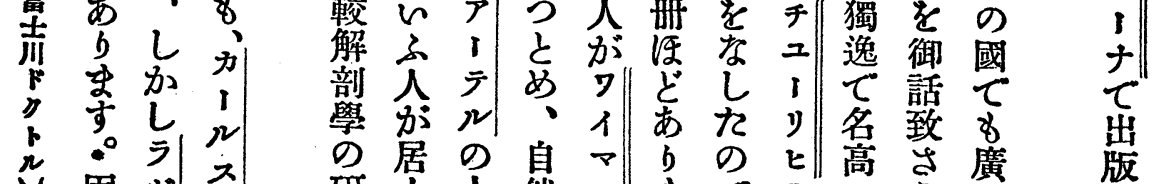

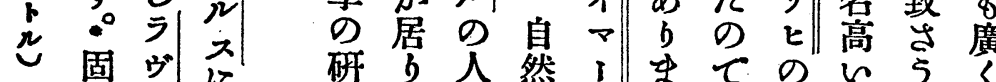

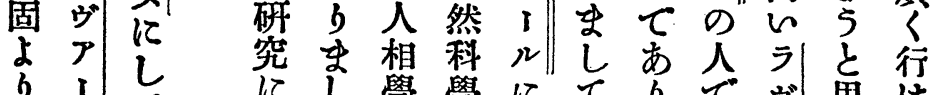

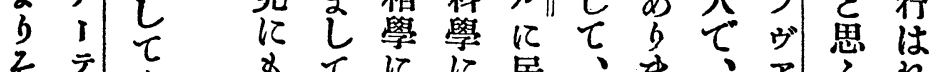

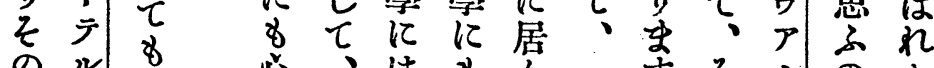

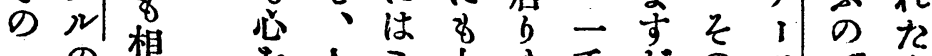

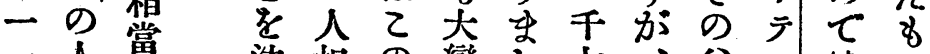

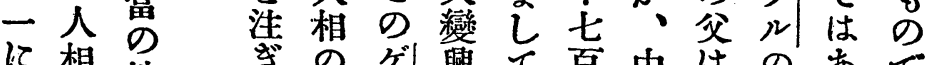

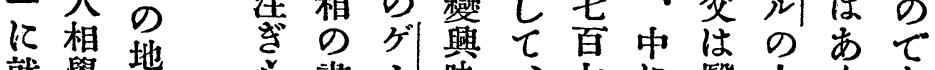

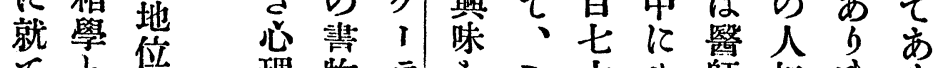

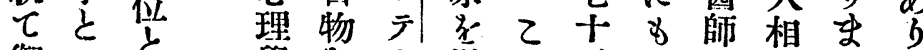

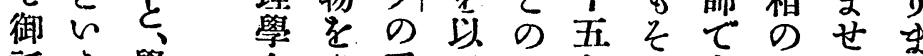

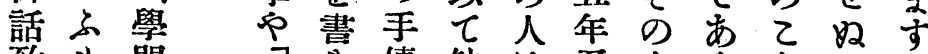

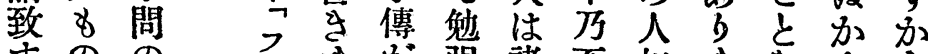
守の 之があ 之一 は全杂 出體人 來論

欢理 z

の 學 の

四乞の著

七基速

b 礎は

生固

守尗

分侄

号立面

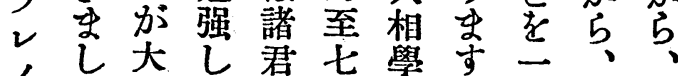

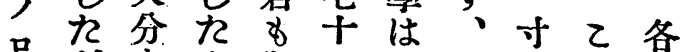

ギが市人御入最乙御之國

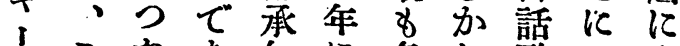

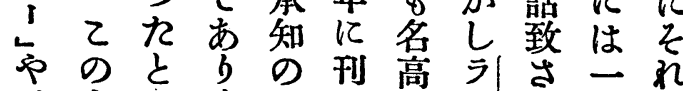

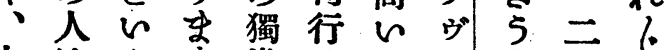

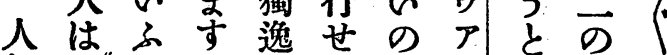

相

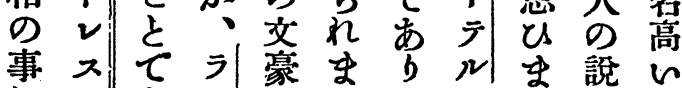

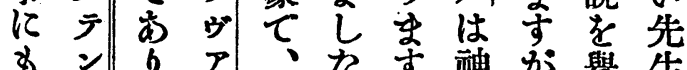

8

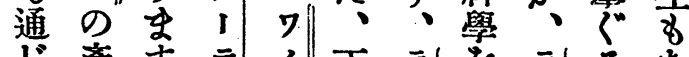

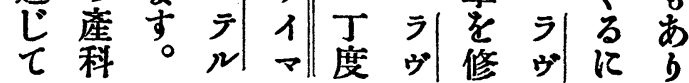

版

䒓

䇂

r

齐|

๑

人

相

學

の

書

物

ic

के

大

體

同

の

事

s

書

r

$\tau$

あ 
の方りるかでな煊從い精さ類尖ま貴乙

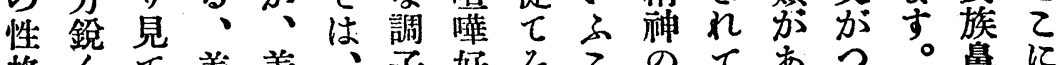

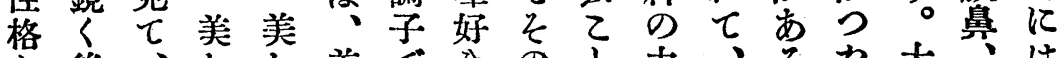

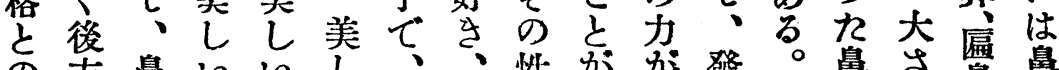

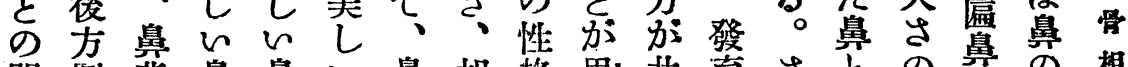

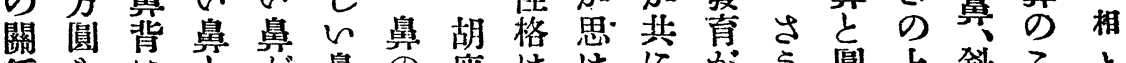

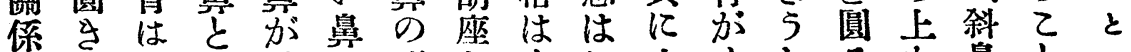

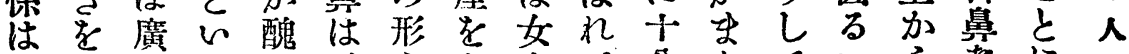
次可々s 通主 且

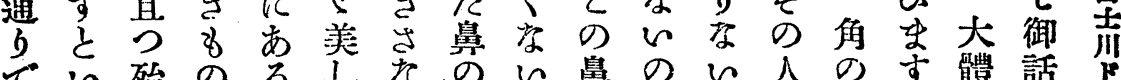

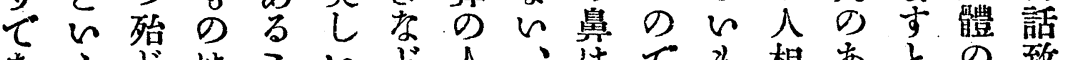

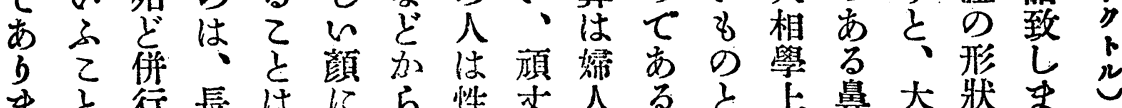

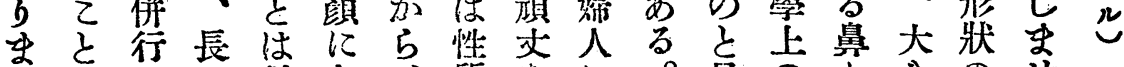

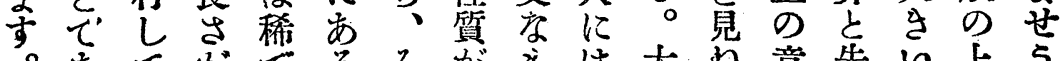

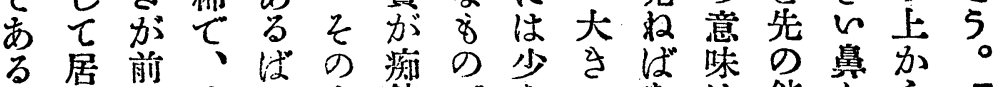

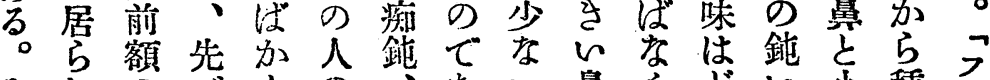

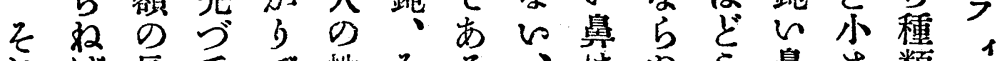

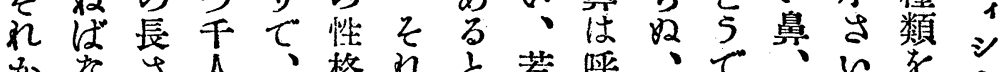

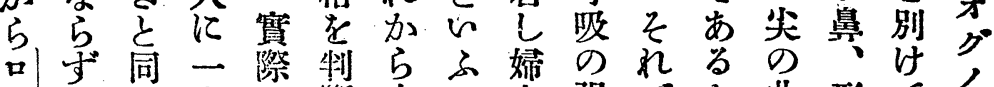

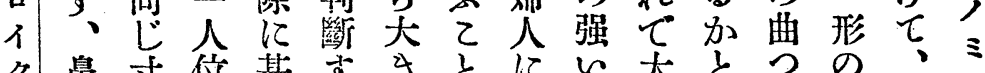

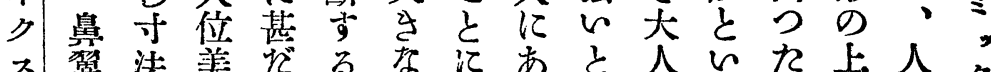

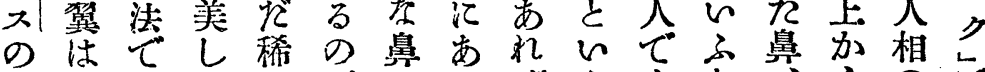

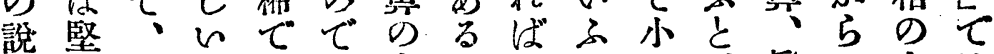

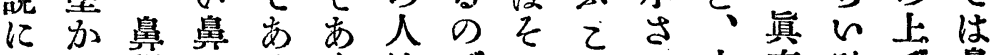

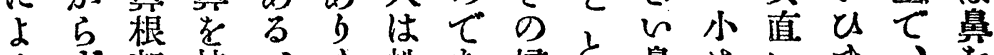

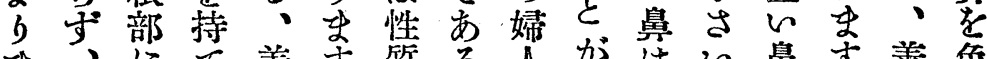

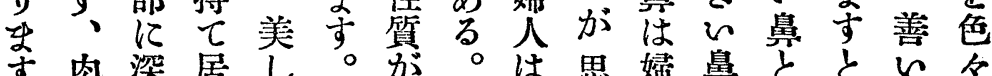
寸肉深居し。分。は思婦鼻とと的々 とはんる

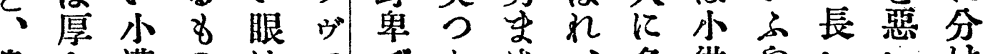

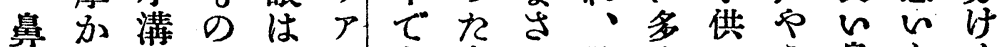

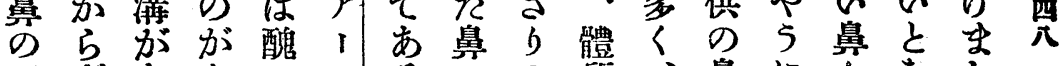

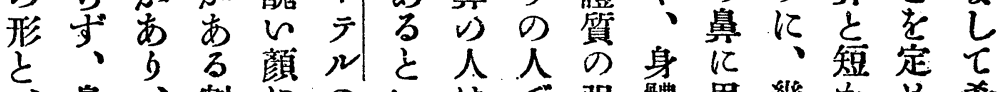
、鼻、割にのんはで强體思幾がめ希

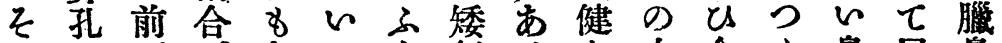

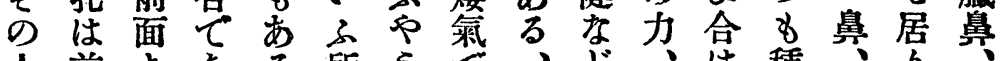
人前よある所 5 て 
あ孔鼻法好鼻 引は篇 bの 較

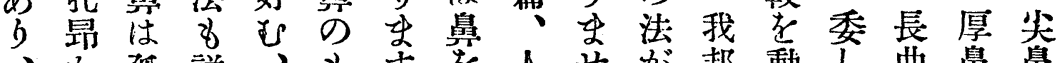

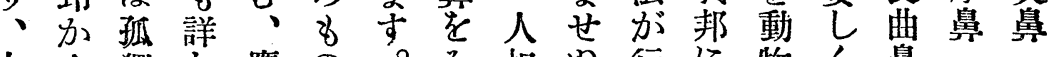
肉ら獨し留の。相收行に物く鼻 骨薄李のく嘴はその水。は的に御 相〈、相說鼻義の形鏡々れ、求話勇遟短

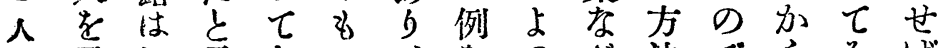

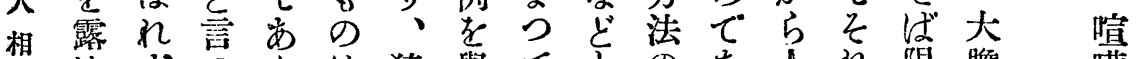

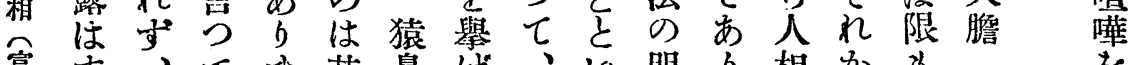

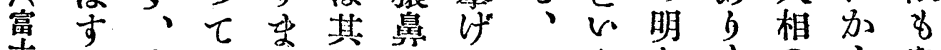

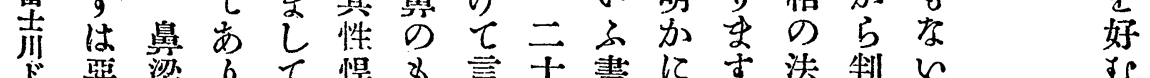

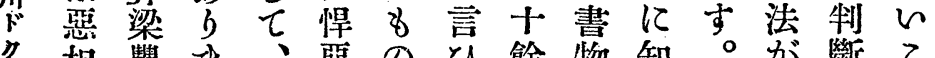

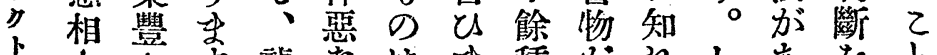

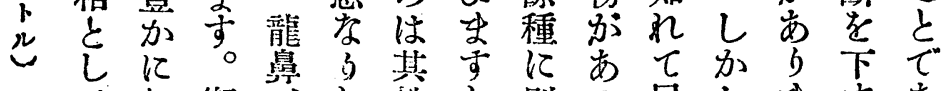
起慨々性之別う居しま卞

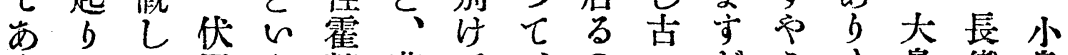

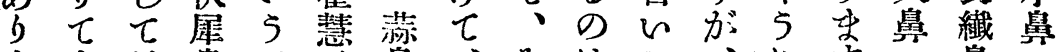

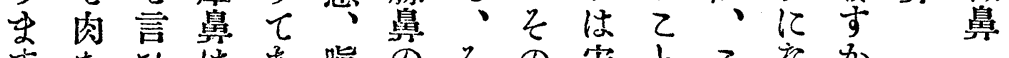

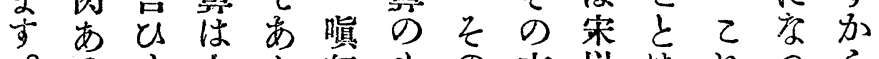
。方ま大怒名の方以はれつ野輕柔

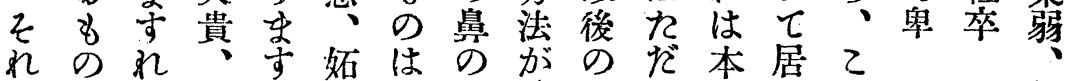

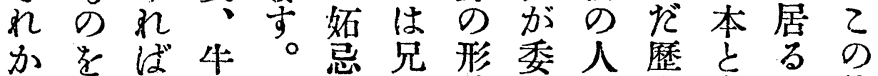

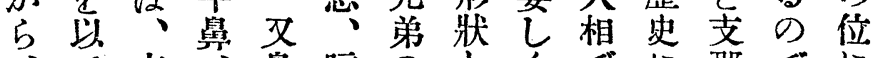
、支鼻暗 人、郡虎の欺情々書、戴加あ致 租良の鼻形多にの の相人はにし缺人てれて承まて

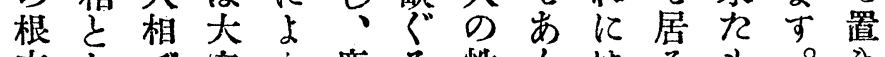

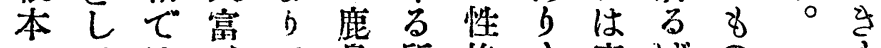

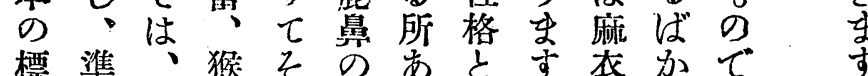

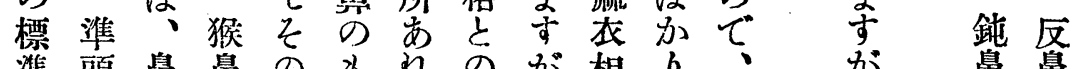

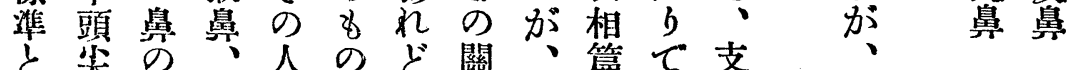

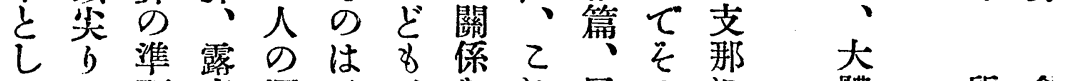
四てて頭答運、、をれ風のに 九 居薄圆鼻命仁心細等鑑方は るく各はを慈に吕の源法古 8 、貧制に毒に書理少に の鼻し賤斷しな說、物立昔

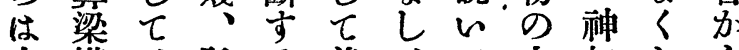
人横、孤る義、七中相わら市 の政鼻峯の狗あに全加之比 


\section{$\sim$ 話 講}

な原見人ら學鼻立嘴にばる貴欲を容

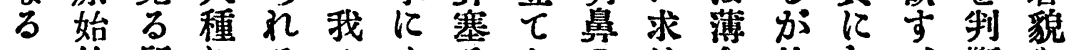

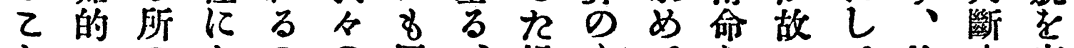

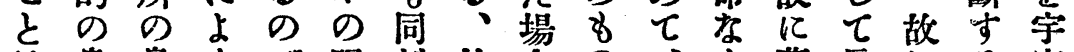

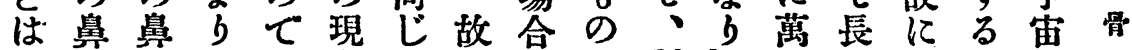

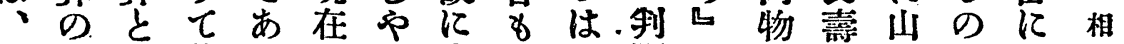

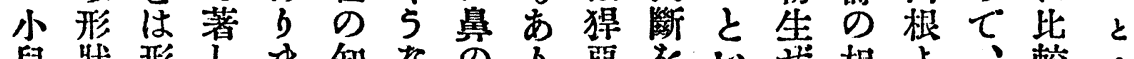

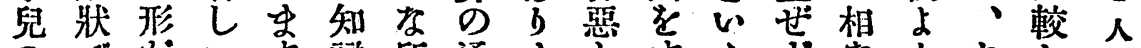

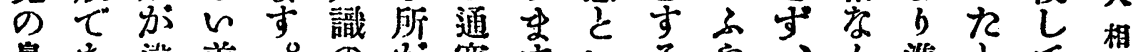

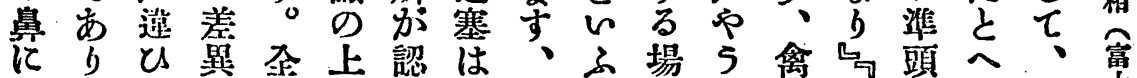

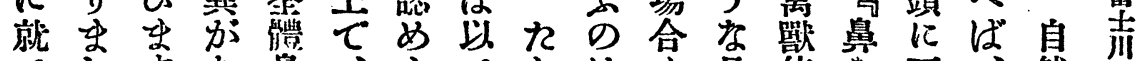

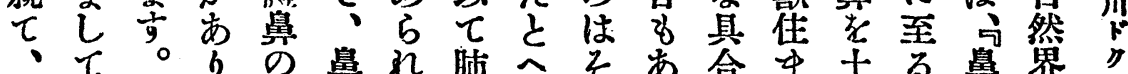

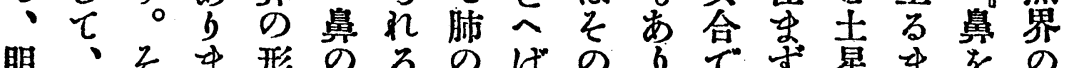

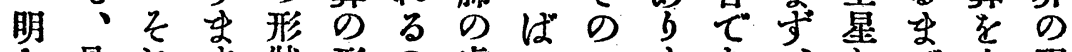

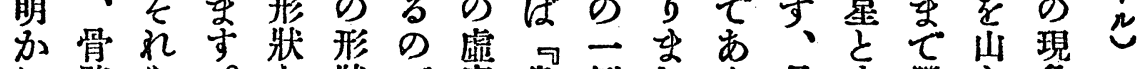

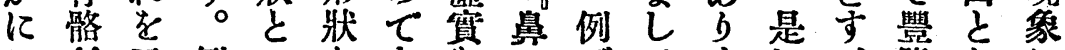

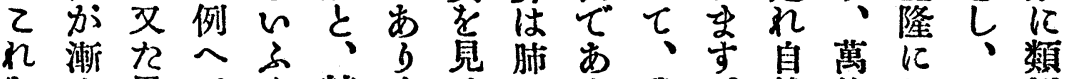

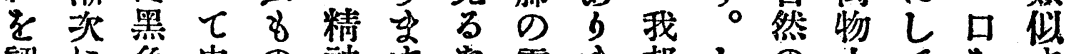

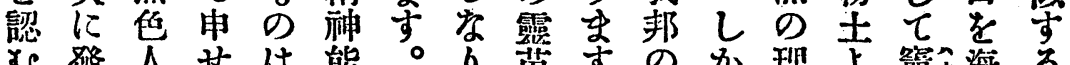

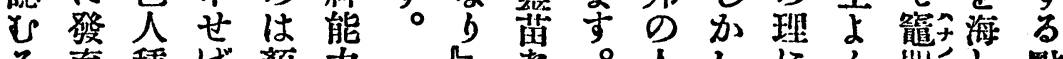

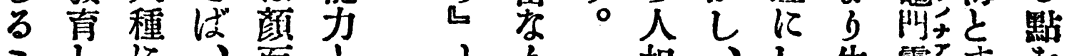

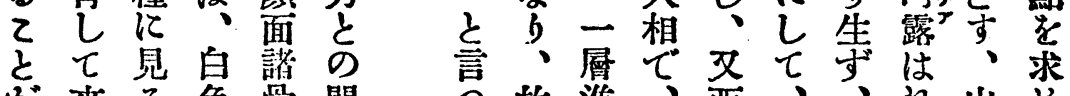

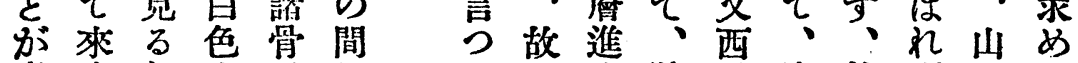

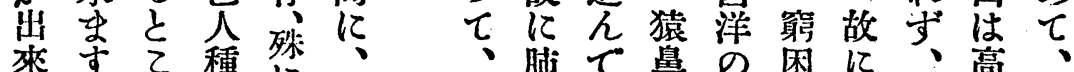

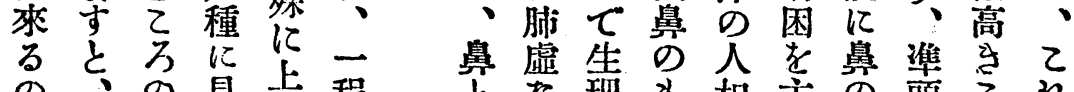

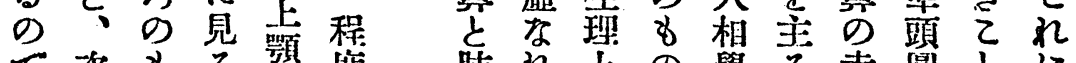

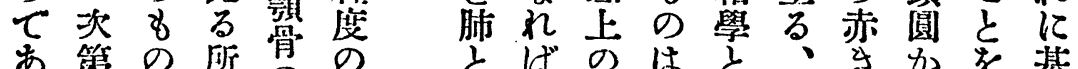
あ第の所骨の学ばのはと、尔基

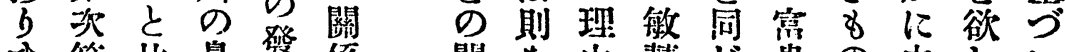

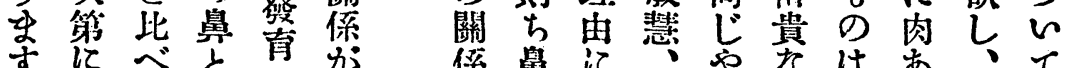

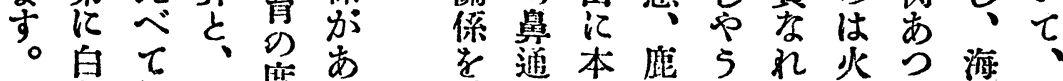

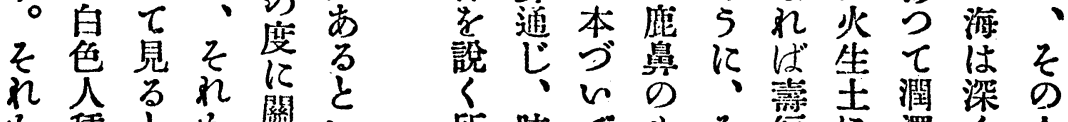

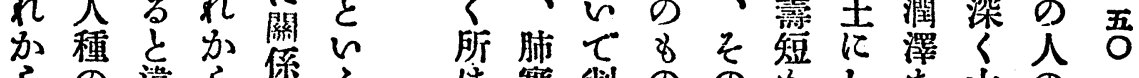

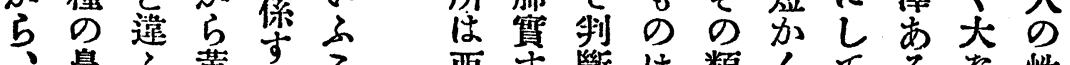

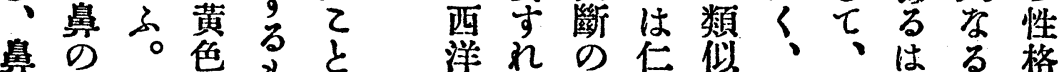

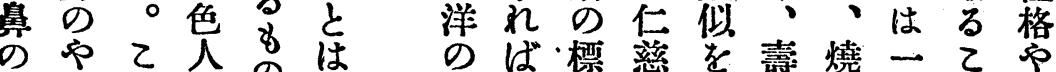

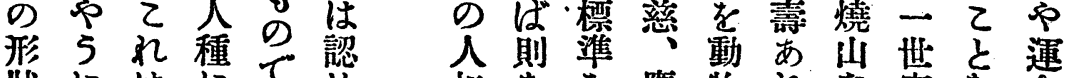

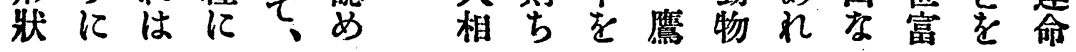




\section{$\sim$ 話 講}

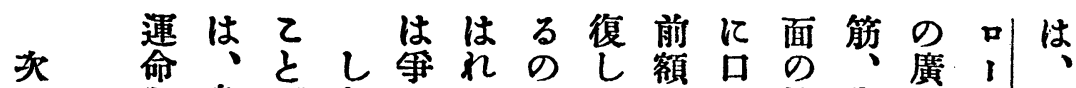

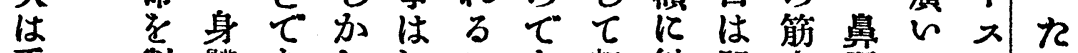

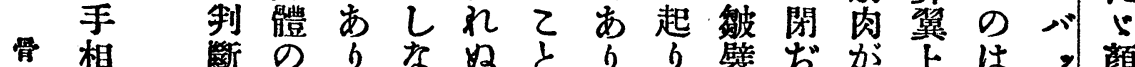

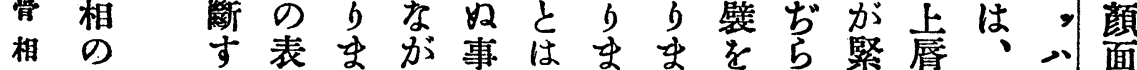

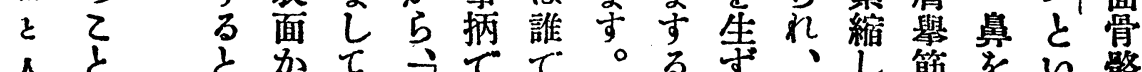

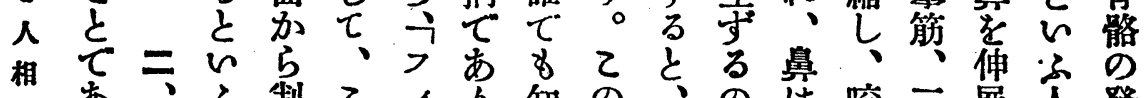

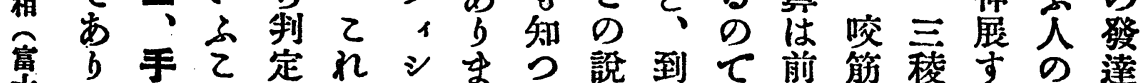

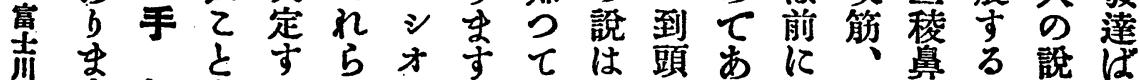

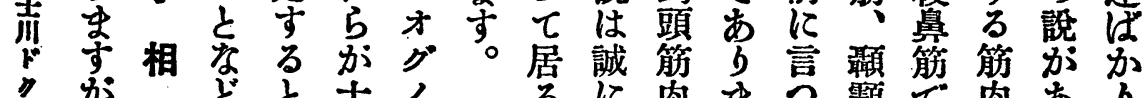

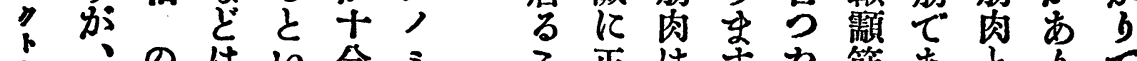

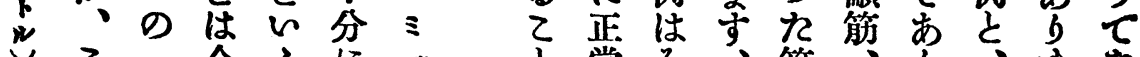

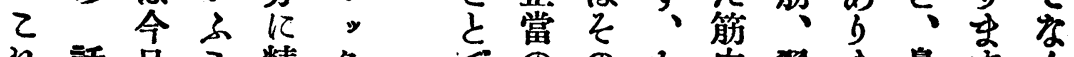

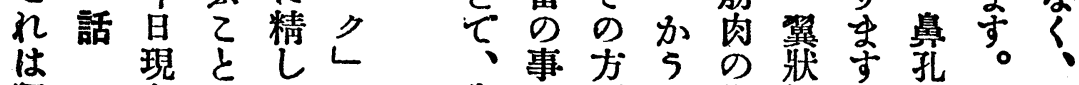

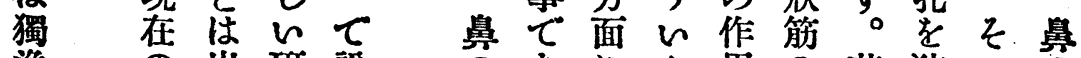

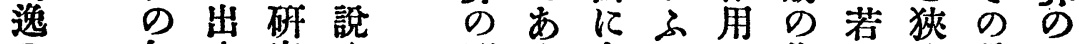

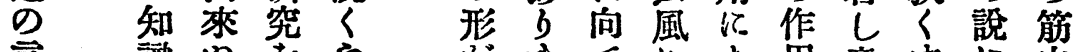

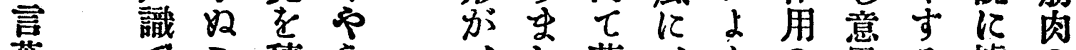

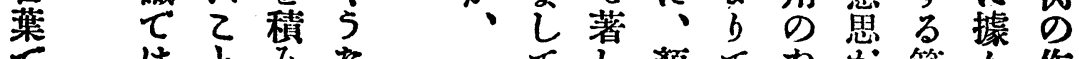

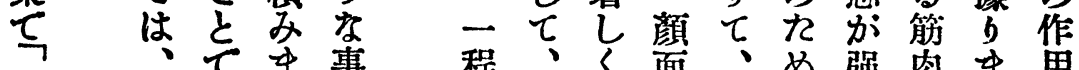

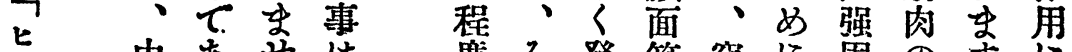

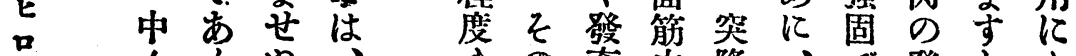

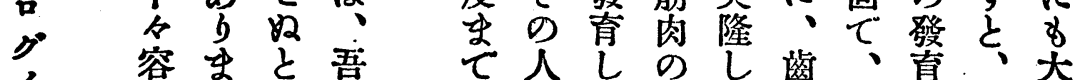

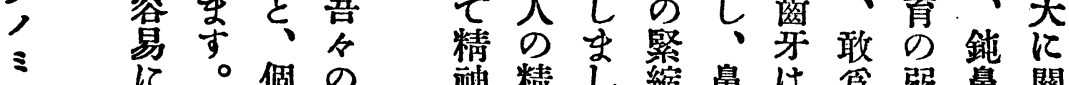
1 に。個の神精し維鼻は篇弱賆關

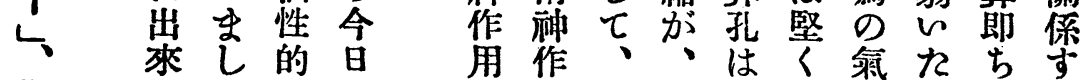

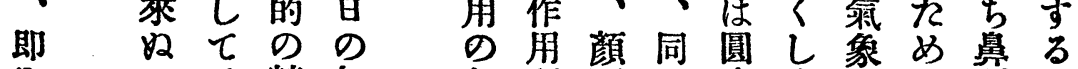

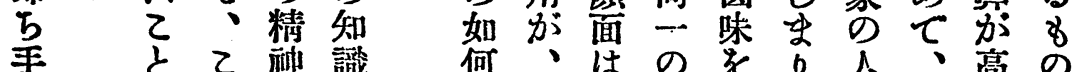

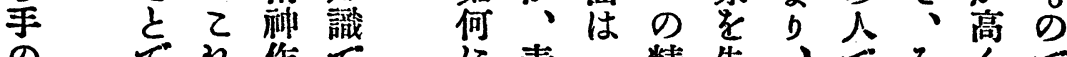

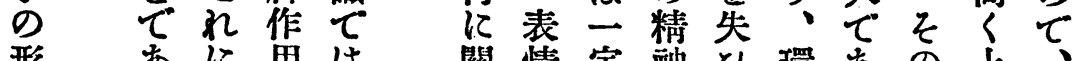

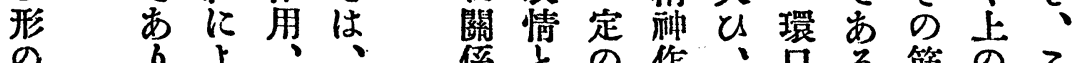

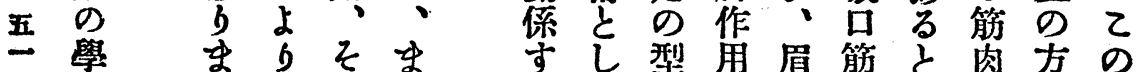

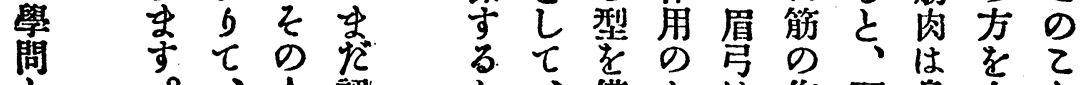
之。人認文、借九は作頭鼻高衣

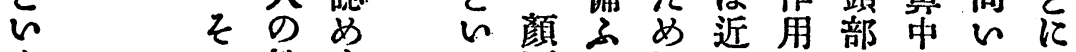

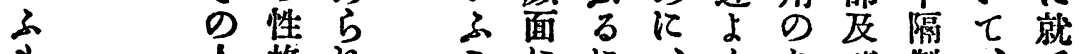

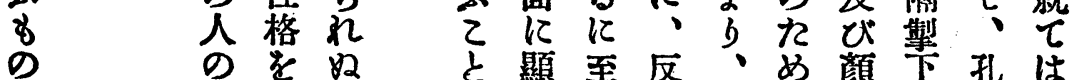




\section{話 講}

点居

風宁

に種

手只

の 結

形 節

に

そ市

的当

12

意の

をの

附手

けの

る人

のは

$\tau$

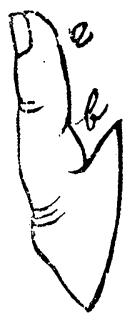

$b$ 理 $b a$

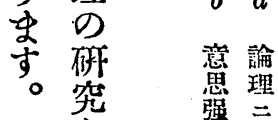

究 强

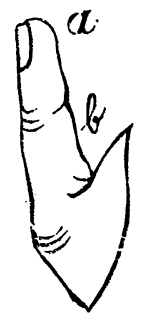

ヘるし美っと

㚆て 家主

祭之型型品骨

壱分、各手方『 相

中形冬角占乎意

\& の、意形話 ᄂ 相

5 手㤎手致 即 富

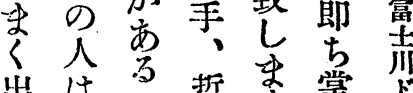

出は年哲掌学

來性放學々面

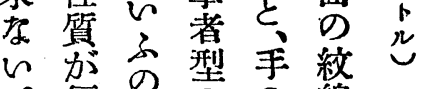

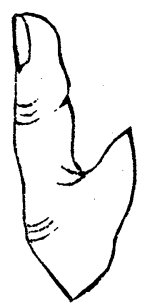

○偏の去の線

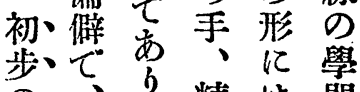

の、、精は問

手、人夺稆䓘型

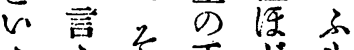

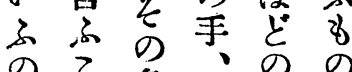

のて角、のの

妵角混别交

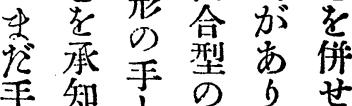

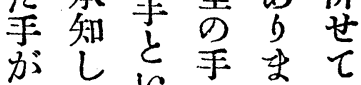

s 發な的亡し

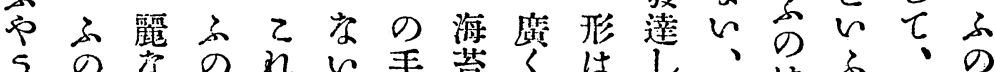

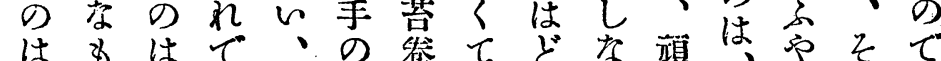

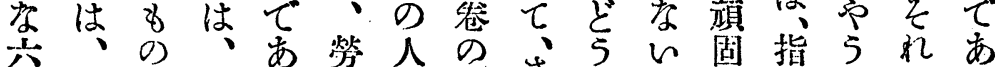

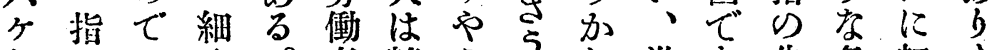

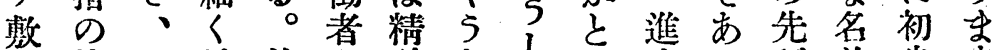

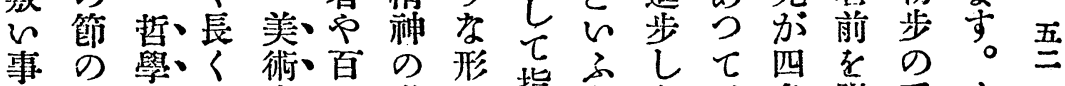

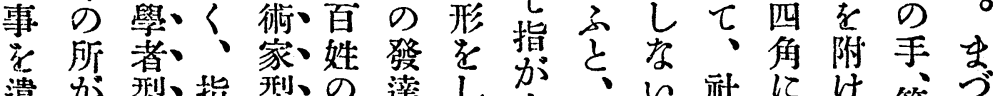

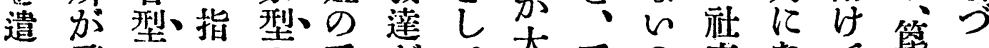

る飛ののの手がて 太手の変なて形

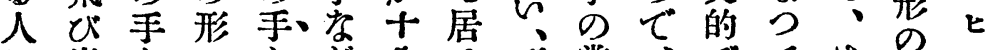

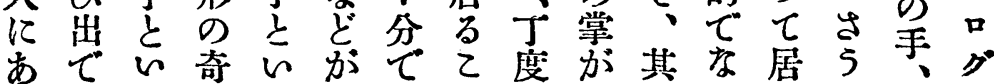




\section{ば委丈れ然ら線ボン人登どて別}

全掌しはの線しと吼の蓬方居けを

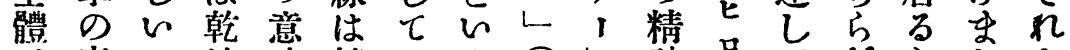

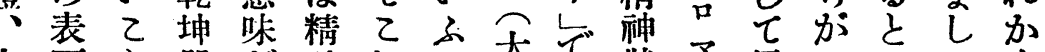

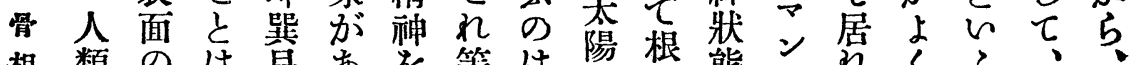

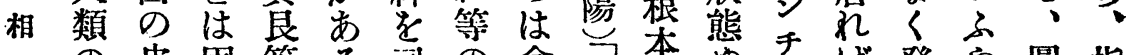

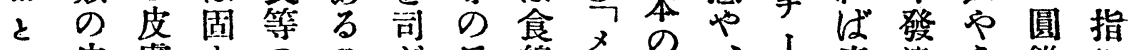

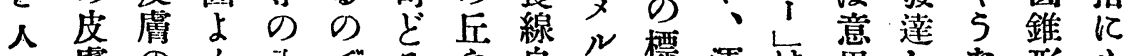

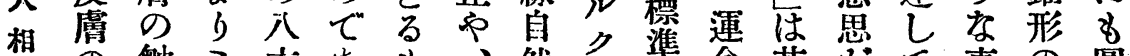

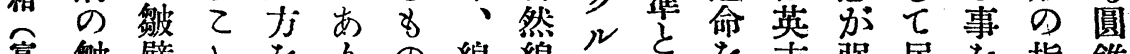

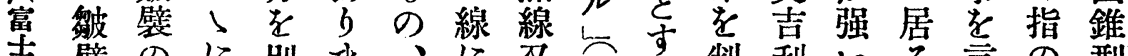

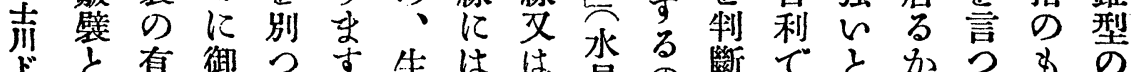

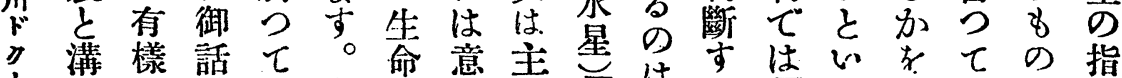

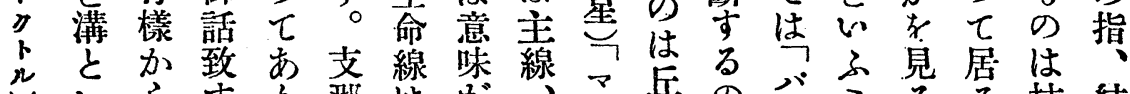

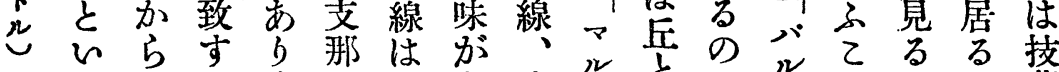

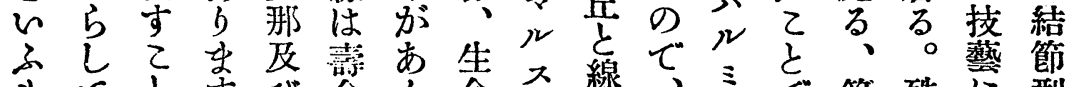

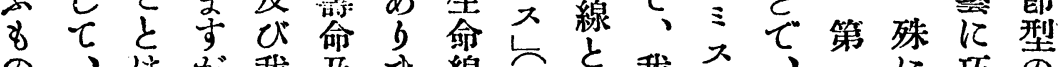

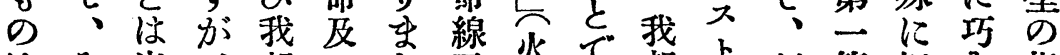

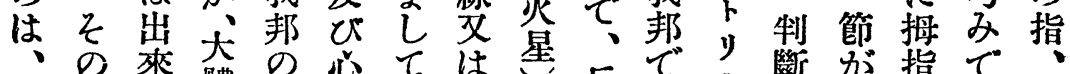

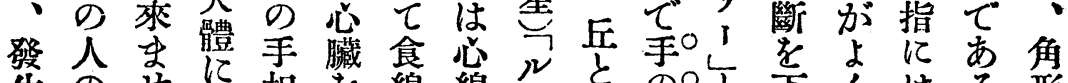

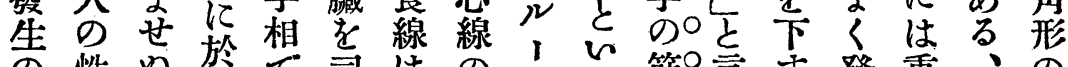

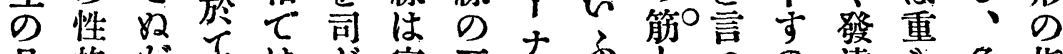

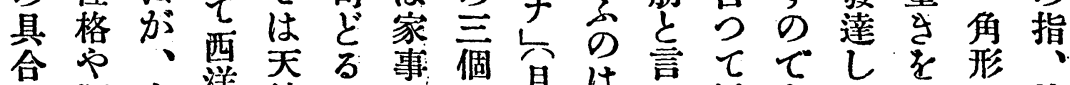

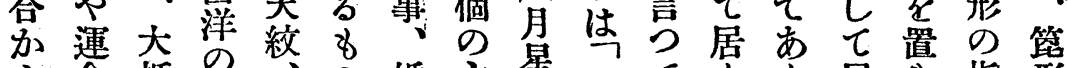

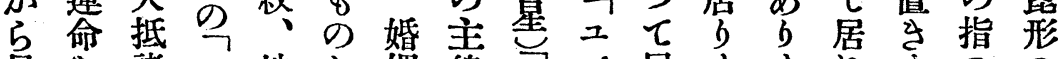
見を諾七地と姻線当ど居士まれ主のの

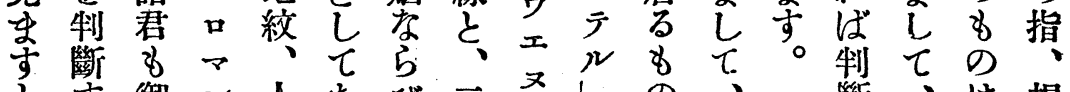

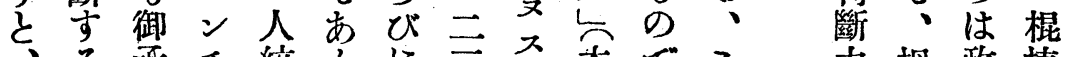

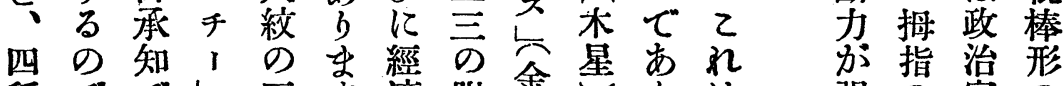

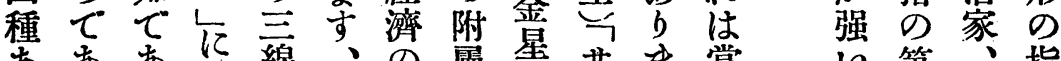

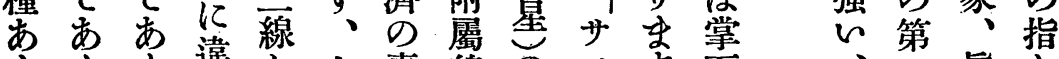

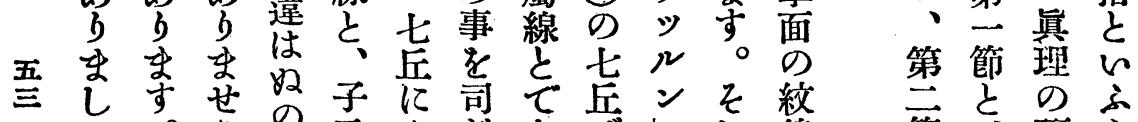

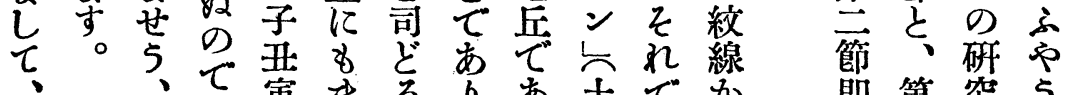

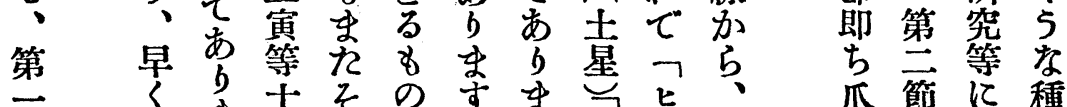

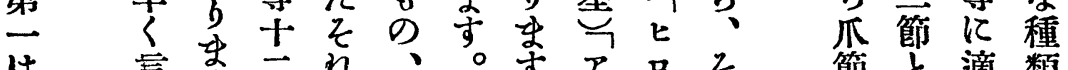

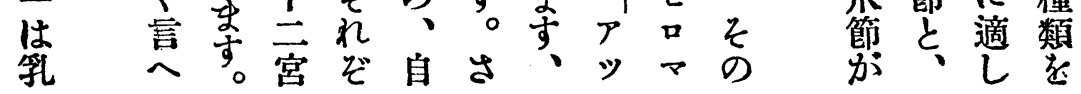



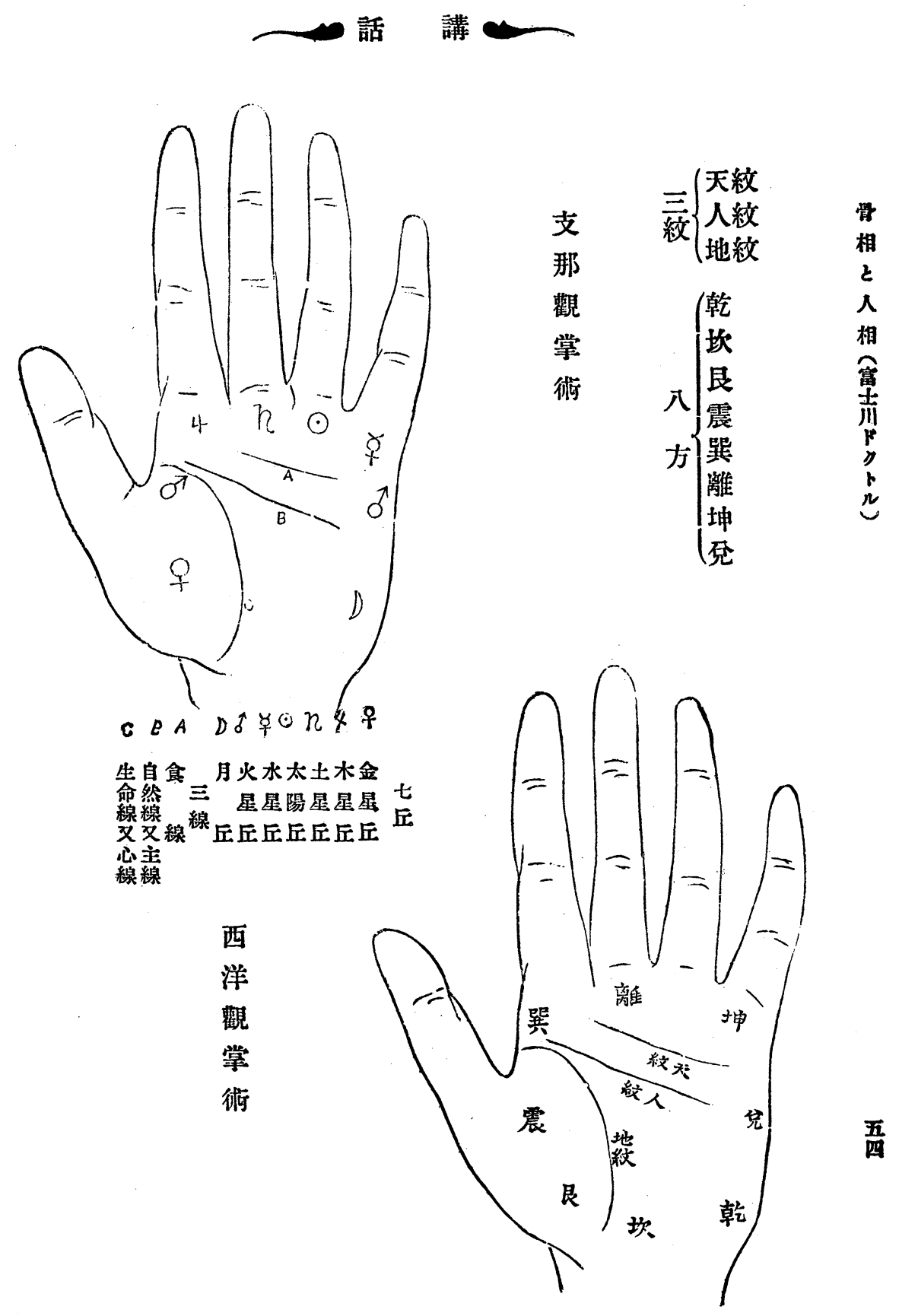


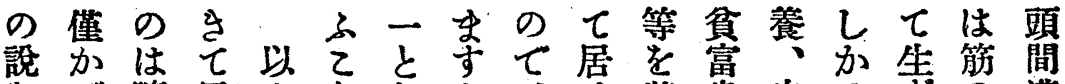

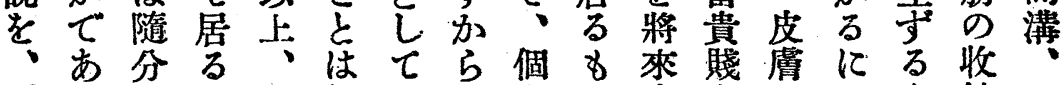

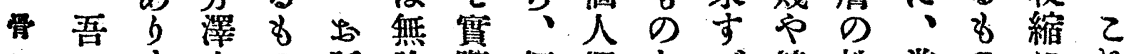
相々屯山の話論際個個乞べ健性掌のにれ

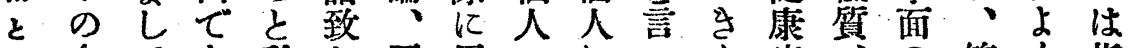
人今て古私し吾用のにつる族、の第 b指

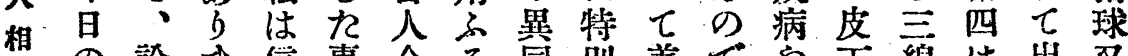

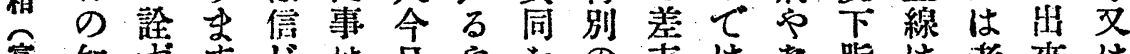

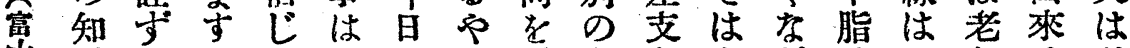

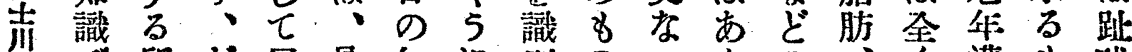

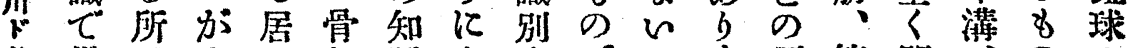

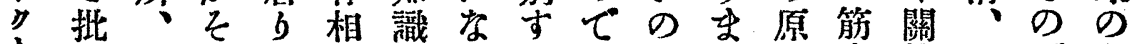

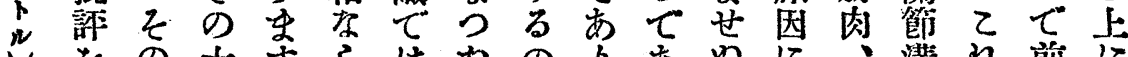

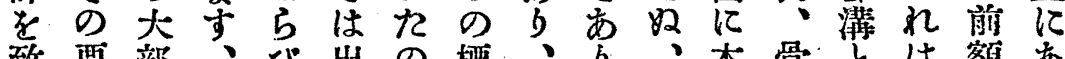
致要部、び出の標、方、本骨とは額あ

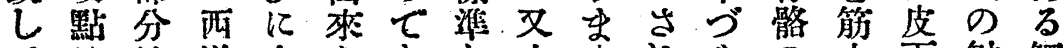

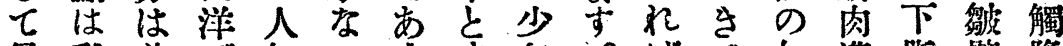

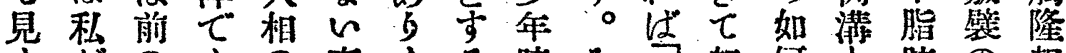

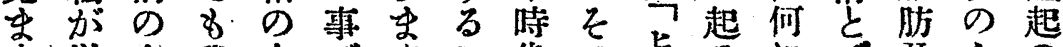

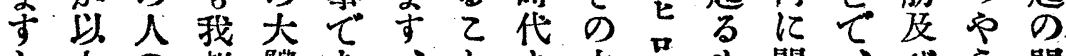

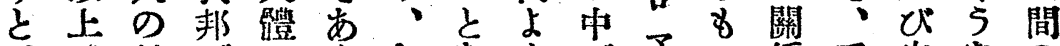

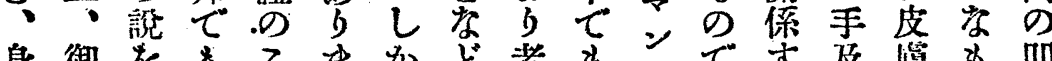

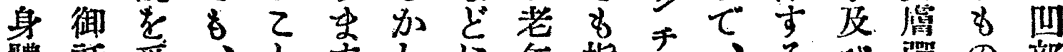
體詀受、と夺しに年指子、る榉の部

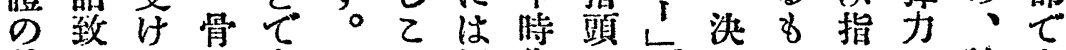

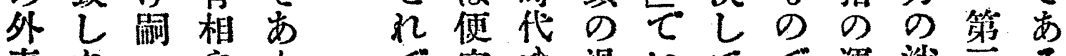

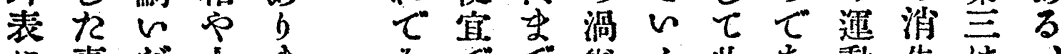

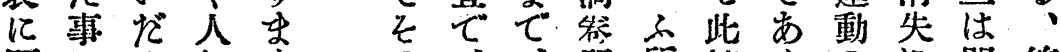

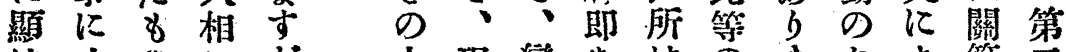

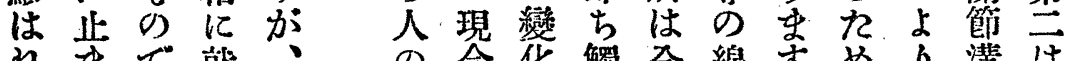

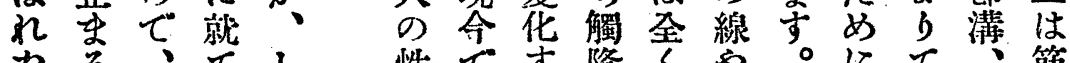

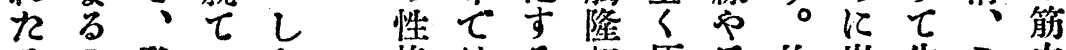
万の覴の加格はる起原兵故出生乙肉

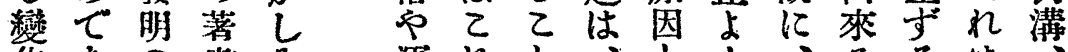

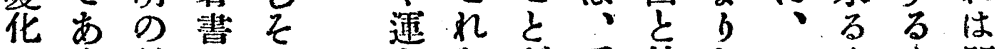

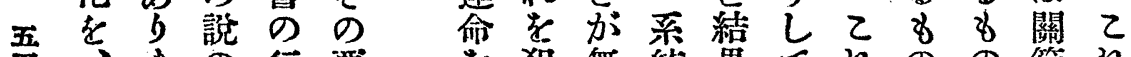
五、里行要を犯無統果てれのの節れ

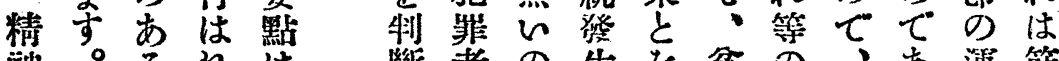

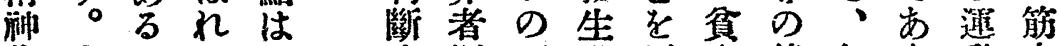

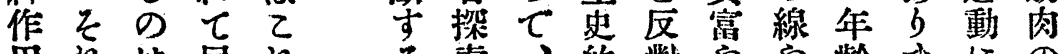

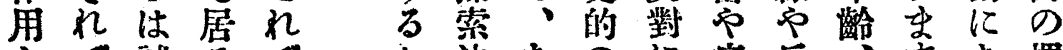

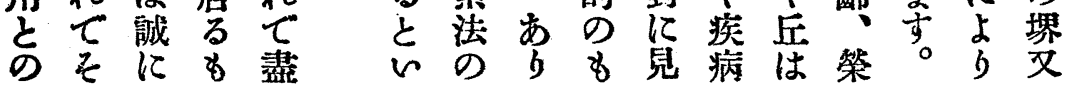




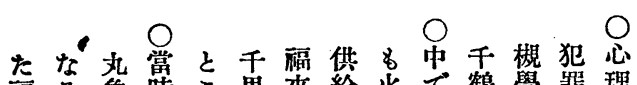

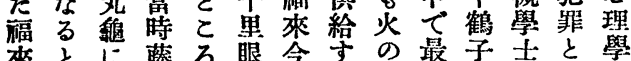
來々心藤乃眼今令最子士と學 博、於原で問村る消名

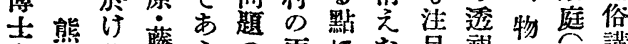

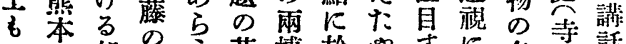

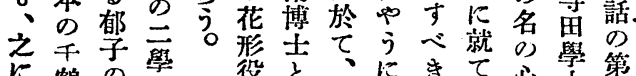

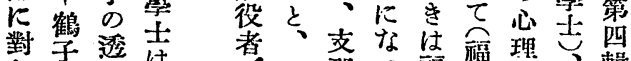

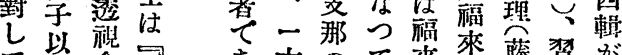
て來念笛あ方のて來來藤習が 何镯哩

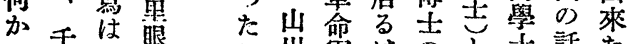

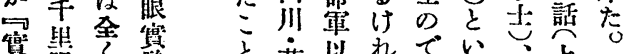

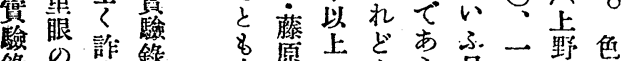

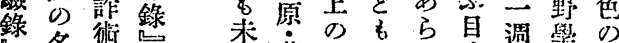

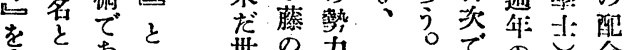
書共古世の力

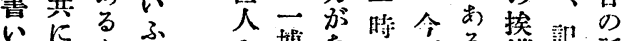

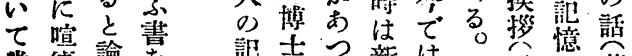

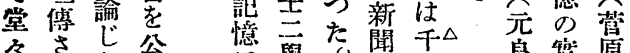

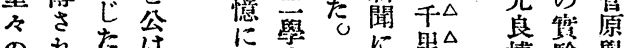

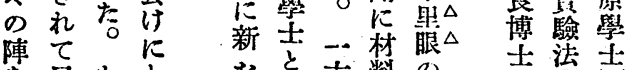

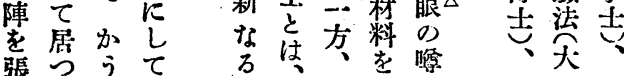

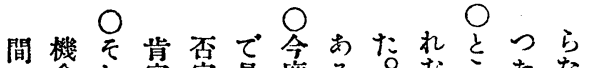

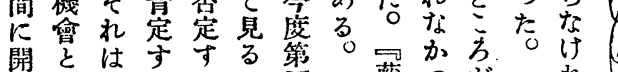
就方方を四藤つが れう諭氣論、輯 たて態焰に長に ら、本范對篇載 ば丸の中すす

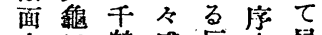
白に鶴盛反文居 心於子て駁加当 にけの文附千 占方方学心鶴 で驗主学て居尒

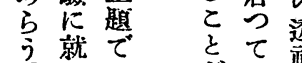

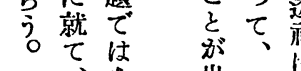

革出乘就 摰け方甞し

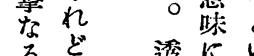
万藩に心 論名視於ふ 加二可透方 學衣能䅐讀 者㖠をなん 藤た た 原要期 千年 待 里はは 眼 張 㟧会一 驗 ひ 年 泰拢 は 梨の餘 ○感經 世 ふi がし の てすた毠 8 万ิ 同の 日 滕をに期 禁至街 あじる得京した たなで所 てか充索 $つ$ じ過闆
はな種普の間 尔事の遍間に には研的の 御出究の 關 關 容來は精係係 赦 難大神を艻相 孛囷作認あと 願 \& 難 用已つ人 ひのででるて 相 㞧でああるた

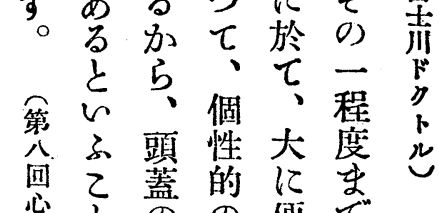
心と盈の 便で 學に形精宜は 通 歸 狀 神市 俗著 落作あ乙 話导顏用るれ 會る面は乙を 演のの の 制 で樣代で知 あ子研あす b究る る

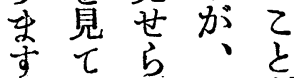
○、L交 $3 飞 \tau$ 出 むの居し、來

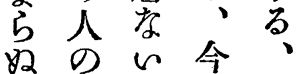
事性: 、日 殊

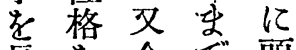
長を今で頭 く制日 研蓋 出衒 $の$ 究

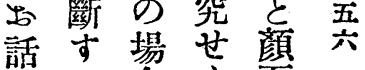
致る合ら面 しとでれと まいはれは しふ、る 腦 えや乙の髓 段らのはと 